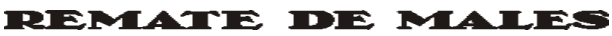

Campinas-SP, v.38 n.2, pp. 791-826, jul./dez. 2018

\title{
EXOFONIA DO HÓSPEDE: POEMAS DE TAWAda YôKo
}

\author{
Marianna Daudt ${ }^{1}$ \\ Andrei Cunha ${ }^{2}$ \\ Michelle Buss ${ }^{3}$
}

Resumo: O presente texto é dividido em duas partes. Na primeira, apresentamos uma autora japonesa, Tawada Yôko, e um livro seu, Wo Europa anfängt E Ein Gast, publicado na Alemanha em 2014. Tawada é uma autora japonesa que publica obras literárias tanto em japonês como em alemão, língua do lugar onde escolheu viver sua vida adulta. O livro em questão inclui textos em prosa e uma sequência de quatorze poemas, apresentados em japonês e alemão, e nunca publicados no Japão. Dentre os principais temas dos poemas, podemos citar a ideia de "hóspede", associada tanto ao estrangeiro como a corpos que vivem em outros organismos; o ciclo da vida e da destruição; o caráter fluido e penetrável da língua; a guerra e seus fantasmas; o corpo da mulher como origem da vida. Outro tema importante desses poemas é o conceito, caro à autora, de "exofonia", ou "literatura que se faz do lado de fora da língua materna”. Propomos uma discussão desse conceito, associando-o a questões políticas, identitárias e tradutórias. Após um breve relato do nosso processo de tradução e de algumas concepções linguísticas e literárias que encontramos em Tawada, apresentamos, na segunda parte, os poemas traduzidos para o português do Brasil, lado a lado com os textos de partida em alemão e japonês.

Palavras-chave: Tawada Yôko; exofonia; hóspede.

1 Mestranda do Programa de Pós-Graduação em Letras da Universidade Federal do Rio Grande do Sul, na linha de Teoria, Crítica e Comparatismo Literário, sob a orientação dos professores Dr. Gerson Neumann e Dr. Andrei Cunha, e bolsista da Coordenação de Aperfeiçoamento de Pessoal de Nível Superior (CAPES): <maridaudt@gmail.com>.

2 Doutor em Literatura Comparada, professor do Setor de Japonês do Instituto de Letras da Universidade Federal do Rio Grande do Sul: <andreicunha@gmail.com>.

3 Mestranda do Programa de Pós-Graduação em Letras pela Universidade Federal do Rio Grande do Sul, na linha Pós-Colonialismo e Identidades, sob orientação da Dra. Jane Fraga Tutikian, e bolsista do Conselho Nacional de Desenvolvimento Científico e Tecnológico (CNPq): <michelle.buss@gmail.com>. 


\title{
A AUTORA, O LIVRO E O PROCESSO DE TRADUÇÃO
}

\author{
"Viajar, para minha avó, significava beber \\ água estrangeira. Outros lugares, outra água. \\ Não é necessário ter medo de uma paisagem estrangeira, \\ mas a água estrangeira pode ser perigosa."
}

(TAWADA, 2014, p. 66)

Para Paul Ricœur (2011, p. 48), a tradução "não implica apenas um trabalho intelectual, teórico ou prático, mas também um problema ético". Ele propõe o conceito de "hospitalidade linguística" (p. 49) para descrever o trabalho da tradutora: ela precisa ser, ao mesmo tempo, hóspede e anfitriã, tanto na língua de chegada como na de partida, ao levar uma cultura de partida para dentro de outra de chegada (em um sentido) e uma leitora de um lugar de chegada ao território do texto de partida (no sentido contrário). A tradução poderia ser, portanto, um "modelo para outras formas de hospitalidade" (p. 49).

No universo poético de Tawada, ela se imagina como hóspede de outras culturas (Londres, Rússia, Alemanha etc.), mas, ao trazer para dentro do seu universo esses outros universos, eles se transformam em hóspedes dentro dela. A autora torna claro seu posicionamento, ao propor o conceito de "literatura exofônica":

A primeira vez que ouvi a expressão "escritores exofônicos" foi em uma fala do pesquisador Robert Stockhammer [...]. Até então, eu já tinha ouvido inúmeras vezes expressões como "literatura de imigrantes" e "literatura créole", dentre outras; no entanto, "exofonia" possuía um sentido mais amplo, designando todas as situações em que a autora se encontra fora de sua língua materna. Afinal, nem todo o mundo que escreve em uma língua estrangeira é imigrante; e nem todo imigrante se expressa em créole. $\mathrm{O}$ mundo de hoje é um lugar mais complexo. (TAWADA, 2003 p. 3) ${ }^{4}$

O "outro" não é uma diferença negativa, mas uma diversidade que enriquece, que soma. O estrangeiro é um hóspede de um país diferente da terra natal, um hóspede que carrega consigo o princípio da renovação, por meio da diversidade e a capacidade latente da aglutinação de mundos,

4 「エクソフォンな作家」という言葉を、今回のシンポジゥムを中心になって企画した研 究者ロベルト・シュトックハンマーの口から初めて聞いた。これまでも「移民文学」 とか「クレオール文学」というような言葉はよく聞いたが、「エクソフォニー」はも っと広い意味で、母語の外に出た状態一般を指す。外国語で書くのは移民だけとは限 らないし、彼らの言葉がクレオール語であるとは限らない。世界はもっと複雑になっ ている。 
visões e culturas. Tawada vai ao encontro do pensamento de Homi Bhabha (1998), que defende que, quando há contato entre uma cultura e outra, independente de quem seja a dominante e a dominada, ocorre um processo de confluência cultural que ele denomina "hibridização".

Movimento, estranheza, intrusão, confluência - essas noções são evocadas pela palavra "hóspede", que carrega uma complexa teia de significados e valores. Entre valores positivos ou negativos, a questão é que "hóspede" se assenta na relação de um alguém que vem de fora para dentro de um sistema, de um país, de um hotel, de uma casa. O estrangeiro, sujeito marcado pelas imagens do "estranho", do "forasteiro", do "intruso", do "outro", configura-se também como uma espécie de "hóspede" no país em que se insere. Esse hóspede tem sua condição traçada pelas mais distintas circunstâncias - desde os processos de desterritorialização, situações de preconceito, desafios de diferenças, até pelo lento processo de integração cultural e social.

Os poemas de Tawada Yôko apresentados aqui em tradução são o resultado de um processo do qual participaram três pessoas vinculadas à Pós-Graduação em Letras da Universidade Federal do Rio Grande do Sul: uma mestranda de Literatura Comparada, formada em Tradução Português-Alemão (Marianna Daudt); um professor do curso de Tradução Português-Japonês e doutor em Literatura Comparada (Andrei Cunha); e uma poeta, mestranda da linha "Pós-Colonialismo e Identidades" e bacharelanda em Tradução Português-Japonês (Michelle Buss).

A heterogeneidade dos vínculos linguísticos e identitários dos participantes do projeto revela, de certa forma, a complexidade identitária da própria autora traduzida. Tawada Yôko5 é uma escritora japonesa que

5 Tawada Yôko [多和田 葉子]. Tawada é o sobrenome, Yôko é o nome pessoal. A ABNT não prevê casos de outras culturas que tenham nomes fora do padrão "Nome Sobrenome". Os nomes japoneses obedecem a uma ordem inversa à nossa (nome de família seguido de nome pessoal): Ono Yôko [小野洋子]; Kurosawa Akira [黒澤明]. Uma exceção pode ser feita, no entanto, para nomes de estilistas, cantores, artistas famosos, inventores etc., pois, nesse caso, o nome é uma marca registrada que muitas vezes sequer obedece às regras de transcrição da língua japonesa (por exemplo, quando há supressão de diacríticas). No caso desta autora, estamos diante de uma complexidade identitária que se reflete na instabilidade da ortografia: ela é uma escritora conhecida no Japão, onde seu nome é Tawada Yôko; no entanto, na Alemanha, seu nomeé Yoko Tawada (na ordem alemã e sem acento). Nos Estados Unidos, onde o sistema de transcrição é diferente do brasileiro, o seu nome pode ser grafado como Tawada Yōko, Tawada Yoko, Yōko Tawada ou Yoko Tawada, dependendo do contexto. No Brasil, o mundo acadêmico nipófono tenderia a grafar o nome na ordem japonesa; um germanista brasileiro, escrevendo sobre a mesma pessoa, escolheria a forma conhecida na Alemanha. Optou-se por manter a ordem japonesa, não por considerá-la a mais correta, e sim por desespero diante da impossibilidade de dar conta de todas essas nuances. 
vive há mais de trinta anos na Alemanha e escreve e publica tanto em japonês quanto em alemão. Sua ampla produção literária abarca vários gêneros, como conto, romance, ensaio, poesia e teatro. Sua literatura possui fortes características multilíngues e transculturais. Na Alemanha, dentre os prêmios importantes que já recebeu, destacam-se o Adelbert von Chamisso (1996), a Medalha Goethe (2002) e o Kleist (2016) - este último, uma premiação tradicional dada em reconhecimento a escritores de língua alemã que promoveram a divulgação dessa literatura para o mundo. A conquista desse prêmio é um marco muito importante na carreira de Tawada, porque insere a autora no cânone literário alemão, mesmo escrevendo em língua diferente da materna. Enquanto este texto estava em processo de edição, Tawada recebeu o Japan Foundation Awards 2018, em reconhecimento por sua contribuição para a cultura japonesa.

Tawada nasceu em Tóquio, no ano de 1960. Era filha de um livreiro. Iniciou o curso de Literatura Russa na Universidade de Waseda. Em 1979, no segundo ano de faculdade, empreendeu uma grande viagem à Europa pela Ferrovia Transiberiana e foi à Alemanha pela primeira vez. Esse momento, por ser bastante decisivo em sua formação, já foi chamado de "início do 'mito fundador' de uma autora" (HOLDENRIED, 2002, p. 169), ${ }^{6}$ pois foi a partir de então que sua escrita ganhou gradualmente a feição inovadora que a levaria a ser reconhecida. Em 1982, Tawada mudou-se para Hamburgo, onde fez mestrado e doutorado em Literatura Alemã Contemporânea, na Universidade de Zurique. Atualmente, vive em Berlim.

A vivência e o trabalho constante com os dois idiomas levam a autora a refletir sobre questões de tradução e sobre as diversas possibilidades de expressão linguística e extralinguística em um texto literário, reflexões que ela externaliza não apenas por meio de ensaios e textos críticos, mas também incorpora à sua produção literária, resultando em uma ficção e em uma poética intercultural que é, ao mesmo tempo, uma teoria linguística. Tawada Yôko busca trazer sua conceitualização da tradução e a sua compreensão da alteridade da linguagem para dentro de seu fazer poético. Tanto em alemão como em japonês, suas obras discutem a dimensão da tradução e os aspectos bilíngues de sua escrita, que a levam a

6 Exceto quando o nome do tradutor está especificado nas referências, as citações estrangeiras foram vertidas ao português do Brasil pelas autoras do artigo. Esclarecemos que, quando nos referimos a Marianna, Andrei e Michelle, autores deste artigo e tradutores, estamos usando propositalmente o gênero feminino, pois são duas tradutoras e apenas um tradutor. 
refletir que a tradução não se dá literalmente ou em sentido restrito, mas teria antes o poder de reescrever e transformar a língua por meio do texto a ser traduzido.

Em "Kleist auf Japanisch" [Kleist em japonês] (TAWADA, 2007b, p. 86), a autora lembra a importância do contato interlinguístico na evolução das línguas, ao contar como a primeira tradução conhecida de Kleist no Japão foi feita por um consagrado autor, Mori Ôgai:

Mori Ôgai foi um excelente conhecedor da antiga literatura chinesa, e esse conhecimento serviu de base para sua tradução de Kleist. A história da tradução literária no Japão começou por volta do século IX, graças ao contato com a literatura chinesa. Naquela época, não havia o procedimento que hoje chamamos "tradução". Em vez disso, procurava-se articular de forma diferente o texto original, o que foi possível por meio dos ideogramas. Uma coisa é certa: os longos anos de contato com a literatura chinesa geraram uma complexidade na língua japonesa, e isso possibilitaria, mais tarde, a tradução da literatura europeia. (TAWADA, 2007b, pp. 87-88)

Como Mori fez com o japonês, ao trazer a literatura alemã por via da expressão clássica chinesa, Tawada combina a cultura europeia e a japonesa, dando destaque à questão da diferença de uma outra língua, o saborear de formas diferentes das usuais, que trazem a possibilidade de conhecer a alteridade linguística e ter contato com o outro.

Na tradução proposta, buscou-se refletir algumas dessas ideias. A tradutora Marianna, que já havia anteriormente trabalhado com a obra de Tawada, convidou o tradutor Andrei para traduzir com ela uma coletânea de poemas da poeta. Esses poemas, que integram o livro Wo Europa anfängt E Ein Gast [Onde a Europa começa \& Um hóspede] (2014), ${ }^{7}$ foram publicados pela primeira vez em 1991, apenas na Alemanha, e nunca no Japão. O livro reúne cinco contos e uma coletânea de 14 poemas, e tematiza os deslocamentos geográficos e linguísticos e a condição do ser estrangeiro em novos espaços políticos e culturais. O conto "Wo Europa anfängt" versa sobre a viagem da protagonista, que atravessa a Rússia pela estrada transiberiana para viajar do Japão à Alemanha (como já dissemos, a própria Tawada realizou essa viagem em 1979). No relato, revela-se o embate cultural vivido pela personagem, que se vê em meio

7 Devido às necessidades específicas deste texto, estabelecemos a seguinte convenção: itálico para línguas estrangeiras, negrito para títulos de livros e itálico e negrito para títulos de livros estrangeiros. 
a uma miscelânea de pensamentos confusos ao se deparar com novas informações, lembranças, sonhos, histórias míticas e anotações, em um desenho narrativo que se assemelha a um mosaico.

Os poemas trazem temáticas diversas, mas têm em comum a presença da interculturalidade, colocada em perspectiva ora política, ora linguística, ora romântica. Na edição de 2014, que serviu de base para a presente tradução, os poemas vêm seguidos de um conto, "Ein Gast", que foi publicado em edição própria pela primeira vez em 1993. Nesse texto em prosa, que tem o mesmo título que um dos poemas da coletânea, surge a materialidade da língua estrangeira na forma da voz feminina de um audiolivro que se infiltra no corpo da protagonista e passa a habitá-lo tanto física como psicologicamente.

O projeto inicial era traduzir os poemas do alemão e cotejar com o texto japonês. Em um momento posterior, Marianna e Andrei decidiram convidar a tradutora Michelle para também participar do projeto. Michelle estava, nessa época, fazendo seu estágio de tradução do japonês sob a orientação de Andrei; além disso, possuía um perfil de afinidade com a escrita poética, pois, sendo ela mesma poeta, já havia publicado dois livros de poesia de sua própria autoria, o que a tornava especialmente indicada para um projeto desse tipo.

A equipe possuía diferentes habilidades e experiências que, combinadas, resultaram em um trabalho produtivo. Isso não significa que não tenha havido desafios. $\mathrm{O}$ conjunto de poemas traz a interessante característica de ter sido publicado apenas na Alemanha, em uma edição bilíngue que os apresenta em língua de partida - o japonês - ao lado de uma tradução, realizada pelo tradutor alemão Peter Pörtner. Além disso, o texto em japonês que acompanha a tradução em alemão foi, talvez propositalmente, formatado em uma tipografia muito pequena, quase ilegível, o que dificultou muito o trabalho de transcrição dos poemas em japonês para fins de tradução. Na verdade, se o texto japonês estivesse impresso em uma letra mais fácil de enxergar, o trabalho dos tradutores teria sido consideravelmente mais rápido.

O fato de os poemas desse livro, originalmente escritos em língua japonesa, terem sido publicados apenas na Alemanha e em edição bilíngue leva a refletir sobre o conceito de originalidade, pois, para o leitor alemão, que não domina a língua japonesa e que representa o primeiro público a ter contato com a poesia, a questão de qual das duas versões seria a original 
torna-se ainda mais indefinida. E, se o texto em japonês não foi publicado no Japão, qual seria o público alvo de um pressuposto "original”?

Desdeo início, ficou claro para a equipe que, idealmente, essa tradução deveria ser publicada nas três línguas em questão, lado a lado: japonês, alemão e português do Brasil. A descontinuidade na relação entre o texto original, a tradução e os leitores da poesia da publicação condiz com as estratégias de estranhamento que a própria Tawada costuma utilizar para demonstrar suas teorias a respeito da tradução. A autora afirma que, em um texto literário, existem muitos "originais" coexistindo lado a lado, em diferentes domínios, que vão se encontrar e realizar sua completude utópica no momento em que cruzam as fronteiras nacionais e culturais (TAWADA, 2007a).

A presente tradução busca, portanto, em consonância com as teorias de Tawada Yôko, trazer à luz mais uma obra original em tradução, considerando a importância do diálogo intercultural e das múltiplas interpretações na recriação de um texto literário, em especial no Brasil um país de imigração e um país com expressiva população de descendentes tanto de alemães como de japoneses. Propõe-se também uma análise de alguns temas, imagens poéticas e ressonâncias intertextuais entre as diversas culturas evocadas nesse texto.

Primeiramente, as tradutoras Marianna e Michelle traduziam isoladamente as poesias de seu par linguístico (alemão-português e japonês-português, respectivamente). A seguir, realizava-se um encontro com os três tradutores, para o cotejo do resultado das duas traduções e a discussão de cada uma das escolhas tradutórias entre o tradutor do alemão, as duas tradutoras do português e os versos em japonês de Tawada. Por fim, a partir dessas discussões, eram analisadas cada uma das interpretações surgidas visando à recriação dos versos, por meio da fusão das diferentes traduções e interpretações. Esse processo durou pouco mais de doze meses e resultou em mais de vinte reuniões de discussão.

Utilizaram-se como fundamento teórico algumas proposições da própria Tawada sobre o posicionamento do tradutor, que ganha grande espaço de liberdade para traduzir e recriar o texto de partida. Para a autora, as "traduções literárias têm de enfrentar aspectos intraduzíveis por meios não convencionais para questionar e quebrar a estética tradicional e transformar um texto no novo texto traduzido" (TAWADA, 1998, p. 35). Assim, por exemplo, no poema "Um caso de amor nos arredores da Sibéria”, o texto japonês apresenta, ao final, uma série de palavras que 
começam com o fonema /o/, como forma de expressar a ideia de que o sujeito poético se tornara um "ômega venenoso":

\begin{tabular}{|c|c|c|}
\hline otoko omuretsu mata wa & O Mann, Omelett oder & homem omelete ou ainda \\
\hline ômukei & Ohm-Messer. & ohmímetro \\
\hline $\begin{array}{l}\text { noriaibasha no naka de } \\
\text { chônekutai nado musubi- }\end{array}$ & $\begin{array}{l}\text { Im Omnibus richtet er sei- } \\
\text { nen Schmetterlingsbinder }\end{array}$ & $\begin{array}{l}\text { no ônibus, ele arruma sua } \\
\text { gravata borboleta }\end{array}$ \\
\hline $\begin{array}{l}\text { naoshi } \\
\text { mienai toshokan no }\end{array}$ & $\begin{array}{l}\text { und verschwindet in einer } \\
\text { unsichtbaren Bibliothek. }\end{array}$ & $\begin{array}{l}\text { e desaparece em direção a } \\
\text { uma biblioteca invisível }\end{array}$ \\
\hline hôkaku e satte ita & O Reis, o Knödel. & orégano ovo de páscoa \\
\hline okome omanjû otomurai & O Beerdigung. & homilia \\
\hline
\end{tabular}

A tradução alemã compensou a ausência do som /o/ no início das palavras com a repetição de uma onomatopeia vocativa $(O)$ e com a palavra Omnibus. Em português, optamos por manter o "ônibus" do alemão (ainda que noriaibasha signifique "bonde puxado por cavalo") para melhor recriar a sonoridade. No entanto, com relação às outras palavras começadas com /o/ em japonês (okome omanjû otomurai, "arroz bolinho enterro"), ao contrário do que fez o tradutor alemão, buscaramse em português palavras que pertencessem ao mesmo universo das japonesas, mas que, ainda que não fossem a tradução de dicionário desses vocábulos, mantivessem uma sonoridade semelhante ("orégano ovo de páscoa homilia"). ${ }^{8}$

Além disso, optou-se por não estabelecer uma hierarquia de originais no momento de traduzir. Tanto o texto alemão como o japonês serviram como ponto de partida para o texto brasileiro, que absorveu significados das duas outras línguas. Por exemplo, a ordem das palavras e das sentenças da tradução segue mais o exemplo alemão - que, mesmo tendo uma ordem de elementos dentro de uma frase bastante diferente da do português, ainda assim é mais próxima do que a do japonês. Essa decisão deliberada de valorizar as duas línguas de forma igualitária (na medida do possível) resultou em uma riqueza textual muito maior, ao final do projeto.

\footnotetext{
8 Seja como for, um omanjû (bolinho assado recheado com pasta de feijão azuki) não tem nada de semelhante nem com um Knödel (bolinho de massa de pão fervido em um caldo), nem com um "bolinho" frito brasileiro, então a sua metamorfose em ovo de páscoa nem é assim tão criminosa - em especial, se levarmos em conta que o poema que abre a coletânea, "Olimpíadas da Idade da Pedra", tem recorrências temáticas relacionadas a ovos, coelhos e fertilidade.
} 
A consciência crítica de Tawada é, em boa medida, alicerçada na concepção de que, a partir da desconstrução dos textos, é possível reinterpretar e ressignificar os elementos fundamentais do conhecimento. A poeta observa que, da mesma forma que uma língua não é passível de pertencimento, ela também não tem a capacidade de representar uma nação e, assim, oferecer-se como lar a alguém (TAWADA, 2007a). Em vez disso, a autora situa-se a si e a sua escrita em um espaço que fica entre a língua e o ser, e onde toda familiaridade é dada justamente pela falta de obrigação de se estabelecer uma identidade ou língua fixa. Esse é o "posicionamento criativo" que ela nomeia "exofonia":

Eu interpreto "exofonia" como sendo um posicionamento criativo, um conceito imbuído de um espírito de curiosidade, uma literatura que busca responder as perguntas: "Como sair da língua materna, que nos rodeia (que nos prende em suas amarras)?” e "O que fazer quando saímos de nossa língua materna?”. O motivo por que se começa a escrever em uma língua que não a nossa pode ter sido, dentre outros, a colonização, ou o exílio; no entanto, se o resultado dessa mudança for uma literatura interessante, não vejo necessidade de se fazer uma distinção entre essa literatura e os textos de alguém que decidiu de livre e espontânea vontade sair de sua língua materna. (TAWADA, 2003, p. 7) ${ }^{9}$

Tawada salienta que não pertence a nenhuma nacionalidade, pois vive em um entre-lugar, o espaço que se forma entre as línguas. Quando propõe a existência de um espaço entre-linguístico como pátria, ou como lar, ela trata da integração fundamental entre a subjetividade humana e os elementos culturais dos quais a língua se revela como vetor essencial, elementos que a formam e que não podem ser limitados, medidos ou controlados por fronteiras. Assim como não se pode falar em apropriação da língua, a apropriação da ideia de cultura por uma suposta nacionalidade fixa também perde sua validade (TAWADA, 2007a).

A desconfiança de Tawada com relação à ideia de nacionalidade é semelhante ao conceito de Heimatlosigkeit [ausência de lar] do filósofo Vilém Flusser. Nascido em Praga e refugiado no Brasil na época do Holocausto, Flusser lembra que, por décadas, dedicou-se a

9これは「外国人文学」とか「移民文学」などという発想と似ているようで、実は正 反対かもしれない。「外から人が入って来て自分たちの言葉を使って書いている」 という受けとめ方が「外国人文学」や「移民文学」という言い方に現れているとした ら、「自分を包んでいる (縛っている) 母語の外によ゙うやって出るか? 出たらどうな るか?」という創作の場からの好奇心に溢れた冒険的な発想が「エクソフォン文学」 だとわたしは解釈した。 
estudar e a tentar compreender a cultura brasileira em seus múltiplos influxos culturais, considerando sempre seu ponto de vista proveniente de uma educação de cultura alemã. Flusser (1992, p. 247) se definia como indivíduo "sem pátria" [heimatlos] por "guardar em si inúmeras pátrias", situação que se refletiria diariamente em seu trabalho, pois, por ser fluente em quatro línguas, sentia sempre como que a exigência de constantes trabalhos de tradução, retradução e de versão em sua vida cotidiana. Seu histórico pessoal de migração (forçada) levou-o a refletir sobre os fenômenos de comunicação interpessoal, bem como sobre os espaços existentes entre os espaços culturais e, especialmente, sobre as pontes que se formam entre tais espaços. Para Flusser, seu "flutuar" por sobre esses espaços culturais força-o a transcender o conceito de pátria, não apenas no sentido de uma vivência concreta, mas também no de refletir teoricamente sobre ele.

Flusser define o imigrante como um homem pertencente ao futuro, um homem sem lar, que, carregando consigo partes do mistério que constitui a idealidade de sua pátria, não se deixa ancorar por ele. Dessa forma, ele se torna como que um espelho através do qual os outros podem se perceber distorcidos e colocar a beleza e a integridade do conceito de pátria em questão (precisamente por isso, esse indivíduo sem pátria é visto como um residente assustador).

Para além da discussão da inviabilidade de se possuir uma língua, Tawada, por sua vez, traz o entendimento de que é por meio dela que os indivíduos se tornam aculturados e mesmo colonizados. No conto "Bioskoop der Nacht" [Cinema noturno], Tawada (2002a) relata uma viagem à Cidade do Cabo e propõe uma reflexão sobre o africâner, língua surgida do contato entre os holandeses e os africanos na época da colonização da África do Sul. Tawada observa o quanto o africâner é uma língua estigmatizada por ser falada majoritariamente pelos coloured, ou seja, a população que se formou como resultado da miscigenação entre africanos e descendentes de europeus. A autora considera que também o japonês e o alemão são línguas estigmatizadas, por diferentes motivos, em alguns lugares, e relaciona a posição de exclusão que pode resultar de uma situação linguística, refletindo sobre o quanto a língua tem a capacidade de controlar os sujeitos a partir de condições exteriores à sua situação. 


\section{O CICLO DO HÓSPEDE}

Os 14 poemas que formam o ciclo poético trazem diversos elementos recorrentes na poética de Tawada, por meio de imagens antitéticas que se sucedem e aludem a diferentes períodos históricos, dispostos de modo não linear e envoltos em uma atmosfera onírica. Elementos como fertilidade, destruição, amor, guerra, vida e morte surgem contrapostos, formando trajetórias cíclicas tanto no nível interno de cada poema quanto do ponto de vista do conjunto dos poemas.

O primeiro poema, "Olimpíadas da Idade da Pedra”, contrapõe a ideia de fertilidade à de destruição, tecendo uma narrativa que reconta a história da Terra, lembrando os danos causados pela energia nuclear e pela bomba atômica. No segundo poema, "Despertar em Londres", o corpo do sonho habita um país estrangeiro de si mesmo, que retorna à casa e se desfaz, no momento em que se acorda:

\footnotetext{
os teus ossos se quebram em estilhaços

que voam por todos os lados

e, um por um, apaixonam-se

no meio da rua deserta

os sete sexos perdidos

ressuscitam de dentro do asfalto molhado

e se erguem dentro de teu despertar ${ }^{10}$
}

A autora retoma sua condição de viajante e descreve algumas percepções sobre estar em um país estrangeiro, como a confusa sensação da mudança dos fusos horários e do clima.

Em "Tourada", o terceiro poema, Tawada aborda a visão consumista e objetificante da vida, contrastando a visão do boi como mero bife, objeto de consumo, à visão do mesmo boi pelos indianos, como ser sagrado. Ao ser sacrificado em nome do consumo, o boi retorna em um plano onírico e espiritual ao acolhimento do lar, o Ganges.

O quarto poema, "Um hóspede" [Ein Gast], tem o mesmo nome que um dos contos do livro e de parte do título do livro como um todo. A posição de destaque é dada ao corpo, em sua função de intermediador entre realidade e percepção, por meio das sensações relacionadas à pele (o tato) e à língua (misturam-se, na língua, a capacidade de degustar à de falar - um “cardápio de poesias"). O corpo também representa um canal de

10 Todos os poemas citados sem número de página estão nos Anexos e correspondem às nossas traduções, que aqui analisamos. 
abertura para o mundo, e a visão do sujeito poético da narradora é tatuada nas costas de um homem ocidental, Marco Polo. O poema inicia-se com a imagem dos Montes Urais ("do outro lado dos Urais/ vem um olá na língua da água"), cadeia de montanhas na Rússia, que demarca a fronteira entre a Europa e a Ásia. Para uma japonesa, a Rússia e os Urais representam algo como o Atlântico para nós, lusófonos - o elemento geográfico, telúrico, que ao mesmo tempo nos separa e nos une a outras culturas. Também podemos fazer referência à própria biografia da autora, que percorreu a Transiberiana em direção à Europa no início de sua vida adulta.

A água, elemento marcante em diferentes poemas de Tawada, é portadora de muitas associações simbólicas, como a fertilidade, o feminino, a purificação, a regeneração e o inconsciente. É interessante refletir também sobre que a água se comporta como o meio pelo qual as grandes navegações expandiram e consolidaram as relações comerciais e culturais entre distintos povos do mundo. A água de Tawada pode ser uma presença sutil, como o asfalto molhado do poema "Despertar em Londres". Em "Um hóspede”, a água surge como uma língua que está do outro lado dos Urais e como a água estrangeira que escorre pela torneira. A água é um elemento capaz de representar o espaço entre as culturas ("e agora corre em suas mãos/ a água de uma terra estrangeira”). A água carrega e dilui o material cultural dos continentes e é o vetor dos primeiros grandes deslocamentos.

Em "sobre a pele de Marco Polo/ estão tatuados/ os meus olhos/ que não conseguem avistar a Europa”, a figura de Marco Polo representa o movimento e a globalização, dinâmica esta que é sugerida no poema, ao nos depararmos com o suposto caso de amor de "peixe cru" (representando o Japão) e "língua de boi" (representando a Europa). Os olhos do sujeito poético estarão tatuados na pele de Marco Polo. Essa imagem evoca uma dimensão sensual ou mesmo sexual ao poema - o suposto homem, encarnado em "língua de boi", com quem o sujeito poético terá uma relação amorosa, sela através do romance a confluência Oriente-Ocidente.

Uma coletânea de poemas transforma-se em cardápio. Essa imagem abre dois vieses de leitura. O primeiro refere-se à transformação do poema em alimento, evocando os ideais românticos da poesia como alimento do espírito. O segundo é um comentário sobre o mundo capitalista, no qual os poemas são comercializados em coletâneas, assim como os pratos presentes em um cardápio. Por outro lado, na cultura japonesa, a comida é um importante elemento identitário, parte essencial da consciência 
do "ser japonês", em oposição ao "estrangeiro". "Peixe cru” traz consigo a relação com a água, e essa água pode referenciar o feminino ou o próprio Japão. "Língua de boi", além de ser um prato europeu muito apreciado no Japão, faz referência à ideia de linguagem - a língua do estrangeiro que é apreendida pelo hóspede; a confluência entre línguas; a obra literária que é construída na linguagem; e, por fim, a tradução, que é uma espécie de relação entre línguas."

"Peixe cru" e "língua de boi" são agentes de um amor transcultural, de um romance globalizante, em que diferentes culturas e idiomas dialogam ao telefone. Os amantes espetam letras à luz de velas ("um garfo reluzente espeta letras/ à luz da vela que arde gasta"). Essa relação com as letras pode remeter a conversas tecidas ao longo de um jantar, ou então, à questão da tradução, que é evocada nos versos seguintes: "manchadas de sangue e sem ferida/ as letras se contorcem de rir/ e soletram na toalha da mesa/ um novo roteiro de amor". Na tradução, comete-se uma violência com a língua. Entretanto, essa violência não transita pela dimensão da crueldade, mas sim, pela de uma paixão violenta: a tradução é oriunda de um embate de visões de mundo, um embate apaixonado entre idiomas e culturas. É a partir desse desconhecimento ou reconhecimento das visões e estruturas linguísticas que nasce uma nova obra traduzida.

O roteiro da nova história de amor, tecido a partir da relação dos amantes, gera uma nova peça ("o sinal que anuncia o começo da peça toca/ as cortinas se abrem/ sobre o palco/ dentro de um sarcófago igualzinho ao meu útero/ nasce/ você"). Essa nova peça é o nascimento de um "você" que pode ser entendido como um filho (oriundo da relação dos amantes) ou uma obra literária traduzida. A imagem do caixão relaciona-se à da morte, mas uma morte que traz uma nova vida ("você"). "Você", palavra que fecha o poema, é munida de força simbólica e conecta-se à palavra "hóspede" do título.

A combinação entre destruição e renovação permeia todo o conjunto poético. No quinto poema, "O retorno", a autora reconta a história de Cinderela que, nesta versão, é assassinada, vítima de uma explosão dentro da abóbora. Busca-se o criminoso, mas não há nenhum vestígio. A história, então, volta-se à contagem cíclica do tempo em agendas e calendários, em uma possível referência ao ciclo da fertilidade feminina e à possibilidade de renovação da vida.

11 Em outro texto, Tawada faz referência a um peixe (o linguado) que é, ao mesmo tempo, uma língua e um ser do mar (Überseezungen, 2002b). 
No poema "Gaivota", Valentina Tereshkova, “a primeira mulher astronauta”, é ao mesmo tempo o espírito santo, que vive no céu; Prometeu, que tem seu fígado devorado; e a gaivota de Tchekhov (2002, p. 111), que é destruída pela frivolidade dos homens:

Uma menina viveu, desde pequena, à beira de um lago, uma menina como você. Ela ama o lago, como uma gaivota; é alegre e livre, como uma gaivota. Mas então vem um homem, avista a menina e a mata, sem motivo nenhum como esta gaivota. ${ }^{12}$

No poema, surgem novas referências ao corpo feminino, que agora dá à luz uma nova geração. A pele, os olhos, os ouvidos e a língua assimilam e confrontam a noção de estranho, buscando decifrar as particularidades culturais de lugares e indivíduos desconhecidos ou em movimento, questionando a própria possibilidade de ler e escrever o outro.

O sétimo poema, "Teclas pretas", tem como eixos temáticos a música, os verbos e a morte. A musicalidade presente na língua se sobrepõe ao alfabeto em si e o aniquila, como numa guerra. O sujeito poético, ao tocar piano, "massacra" os verbos, tornando-se um assassino. Os sons têm significativa relevância na poética de Tawada. No oitavo poema, "Um caso de amor nos arredores da Sibéria”, o sujeito poético se coloca como um "ômega venenoso", categorizado como "especial". Tawada transmite heranças linguísticas, históricas e culturais pertencentes a diferentes lugares e momentos, por meio de atos de memória e de engajamento crítico com as tradições históricas e culturais japonesa e alemã.

Em "O realejo do século XXI", o poema 9, temos a imagem deslocada de dois objetos cuja essência consiste no ato de girar, lembrando novamente as trajetórias cíclicas associadas à terra, ao tempo e à vida: um realejo colocado extemporaneamente no século XXI e uma roda gigante pairando no ar. O sujeito que surge devora a si mesmo, deixando restar apenas o órgão genital, que, como na lenda de Urano e do nascimento de Vênus, ressurge, dando lugar a um corpo de mulher. Ao final, essa mulher, mãe, também devorará a lua e tudo o que existe, em um ciclo que leva ao completo nada.

No poema 10, "Um método de rejuvenescimento", Tawada joga o leitor em um abismo, onde se desenrolarão três curtas histórias de homens

12 "[...] a young girl has lived since childhood on the shores of a lake, a girl like you; she loves the lake, like a seagull, and is happy and free, like a seagull. But a man comes along, sees her and idly kills her - like this seagull”. 
que, tendo envelhecido e adoecido (física e mentalmente) no ritmo da guerra, não podem recuperar seus tempos de vida, perdidos em função dos caprichos abjetos dos governantes.

A escrita de Tawada desconstrói expectativas com relação aos paradigmas culturais tradicionais e leva o leitor a reconfigurar imagens e palavras por meio de processos contínuos de sugestões e transformações. Assim, por exemplo, no poema "O jardim do encontro", um pessegueiro alude a uma dor ou aflição mental, ao mesmo tempo que ecoa intertextualmente o Éden bíblico, o jardim da Rainha de Copas de Alice no país das maravilhas e o casal primevo da mitologia japonesa, deslocando todas essas referências para o contexto da contemporaneidade. Um fruto do pessegueiro amadurece e cai em um tabuleiro de xadrez que há no jardim (como o kireji de um haicai).

Em “Funeral sem cadáver”, poema 12, encontramos imagens orgânicas, em situação de decomposição, como "cabelo podre e ossos secos", em contraposição a imagens imateriais ou desmaterializadas, como "apenas nos funerais essas crianças aparecem/ não têm solas nos pés/ não deixam pegadas". Esses elementos compõem uma atmosfera fantasmagórica, que novamente denuncia a guerra.

No poema 13, "Um dia de folga da poeta", a partir de um pequeno gesto, gera-se uma série de consequências em ondas (marítimas e eletromagnéticas) que, como um efeito borboleta, ao final, levam a mãe da poeta a cortar com a faca "a cabeça da História da Literatura", como na passagem bíblica sobre Judite e Holofernes.

O poema 14 chama-se "Hospital musical", e é o último da coletânea. Destacam-se nele as ideias de retorno e aniquilamento - ou, antes, dissolução, retorno ao nada, ou ao todo -. A personagem leva três tiros na nuca e surpreende-se por não morrer, pois as surreais balas que a atingem são moles e lentas. De qualquer forma, a personagem repousa em um lugar que fica entre o mundo dos vivos e o dos mortos, representado mitologicamente pelo rio Sanzu (uma imagem análoga à do Rio Estige, que foi a solução preferida pelo tradutor da versão alemã). Tawada retoma o envelhecer, caminho de retorno à comunhão do corpo com o universo: "eu envelheço pelas frestas entre meus dentes". A personagem põe-se a andar de costas por caminhos que desconhece. Ao final dessa trajetória, o rosto e a boca já não têm mais utilidade: "murchem! olhos inúteis boca inútil”, e há apenas um "rosado crepúsculo que começa a se desenrolar". O 
rosto se dissolve e passa a ser parte de uma massa orgânica sem sentidos, "uma parte das costas".

Analisando-se os poemas como um todo, observa-se que, ainda que a maioria dos temas estejam entremeados, no início existe um ritmo frenético, uma corrida pela vida - que nunca deixa de ser vista como um ciclo constante de nascimento e morte - uma história da Terra e muitas referências à fertilidade. Ao longo da coletânea, são abordadas as temáticas do deslocamento, do conhecer novos espaços e sujeitos culturais, além de questões políticas e sociais, como as críticas ao consumismo e às guerras. Ao final, os poemas se adensam no tema da morte, e as denúncias das catástrofes da história se tornam mais agudas. O último poema propõe um aniquilamento final e o início de um novo ciclo.

Escrever, para Tawada, é expandir as visões de mundo. A escrita é um ato de vida e de resistência para alguém que, como ela, transcendeu a margem de ser mulher e de ser estrangeiro. Tawada é a transcendência de fronteiras e países. É ser palavra no mundo.

Este trabalho, que transita por diversos universos linguísticos e se apresentou desde o início de modo multidirecional, demonstrou a possibilidade ou, ainda mais, a necessidade da utilização de estratégias múltiplas de tradução. Parte importante da estética de Tawada é utilizar palavras desviantes das de uso familiar na língua. Por meio da recriação de algumas passagens, a poesia tornou-se mais proeminente. Se, por um lado, existe uma tradução literal, mesmo quando o contexto da palavra não tenha sido transferido para o texto de chegada, elementos seus como origem, som ou partes do seu universo contextual foram considerados. Em outras passagens, observam-se algumas formulações que, à primeira vista, pareciam se desviar do primeiro texto em japonês, ou em alemão dependendo de qual foi utilizado como base-, mas que estão intimamente relacionadas com a tradução literal de uma determinada palavra, especialmente se o todo é levado em conta. Portanto, na tradução da poesia de Tawada, os elementos livres e literais estão intimamente relacionados, indicando a necessidade de se superar o dualismo da questão da liberdade ou literalidade da tradução.

Traduzir os poemas de Tawada Yôko foi como fazer um trabalho manual. Muito mais do que seguir um roteiro pré-estabelecido, um passo a passo, foi preciso que cada um dos tradutores estivesse aberto para o novo e desafiador universo tawadiano, no qual a vivência tradutória e pessoal de cada um se tornou fundamental no manuseio dos textos, na 
(re)construção de imagens, sonoridades e sentidos. Tal qual um artesão que domina inúmeras técnicas, mas que, ao se desafiar a criar algo, precisa estar aberto para a experiência que esse algo proporciona, o tradutor precisa também, toda vez que se depara com a oportunidade de uma tradução, estar aberto a um novo universo criativo. Afinal, a tradução é, como afirma a própria Tawada (1998), um ato de recriação. O tradutor pode ter a liberdade para interpretar e recriar um texto por meio da tradução, sendo benéfico o contato e o diálogo intercultural e vivencial que surge desse processo.

\title{
GUEST EXOPHONICS: POEMS BY TAWADA YÔKO
}

\begin{abstract}
This text has two parts. First, we present a Japanese writer, Tawada Yôko, and one of her books, Wo Europa Anfängt E Ein Gast, published in Germany in 2014. Tawada was born in Japan, and writes in Japanese and German - German being the language of the country where she chose to live her adult life. Wo Europa Anfängt \& Ein Gast includes prose texts and a series of fourteen poems, presented in Japanese and German, which have never been published in Japan. Among the main themes of this collection, we may find: the concept of "host", associated with that of the foreigner and the bodies of other living organisms; the cycle of life and destruction; the flowing and penetrable nature of language; war and its ghosts; the female body as the source of all life. Another important theme is "exophony", a concept dear to the author - a "literature that is made outside the mother tongue". We propose a discussion of this concept, associating it with political questions, as well as issues of identity and translation. After a brief account of our translation process and a discussion of some linguistic and literary conceptions we find in the works of Tawada, the second part of the essay presents the translation to Brazilian Portuguese of the 14 poems that are included in the book, side by side with the texts in German and Japanese.

Keywords: Tawada Yôko; Exophony; Host.
\end{abstract}

\section{$\overline{\text { REFERÊNCIAS }}$}

ANDERSON, Susan C. Surface Translations: Meaning and Difference in Yoko Tawada's German Prose. Seminar: A Journal of Germanic Studies, v. 46, n. 1, fev. 2010, pp. 50-70.

BHABHA, Homi. O local da cultura. Trad. Myriam Ávila, Eliana L. de Lima Reis e Gláucia Renate Gonçalves. Belo Horizonte: UFMG, 1998.

BREGER, Claudia. Mimikry als Grenzverwirrung. Parodistische Posen bei Yoko Tawada. In: BENTHIEN, Claudia (org.). Über Grenzen. Stuttgart: Metzler, 1999, pp. 176-206.

COSER, Stelamaris. Híbrido, hibridismo e hibridização. In: FIGUEIREDO, Eurídice (Org.). Conceitos de literatura e cultura. Juiz de Fora: UFJF, 2005, pp. 163-188. 
FLUSSER, Vilém. Bodenlos. Eine philosophische Autobiographie. Düsseldorf: Bollmann, 1992.

HOLDENRIED, Michaela. Eine Poetik der Interkulturalität. In: GUTJAHR, Ortrud (org.). Fremde Wasser. Tübingen: Claudia Gehrke, 2012, pp. 169-185.

KAINDL, Klaus. Of Dragons and Translators: Foreignness as a Principle of Life. Yoko Tawada's "St. George and the Translator". In: KAINDL, Klaus; KARLHEIZ, Spitzl (orgs.). Transfiction: Research into the Realities of Translation Fiction. Amsterdã: John Benjamins, 2014, pp. 87-102.

RICEUR, Paul. Sobre a tradução. Trad. Patrícia Lavelle. Belo Horizonte: UFMG, 2011.

SAID, Edward W. Orientalismo: o Oriente como invenção do Ocidente. Trad. Rosaura Eichenberg. Rio de Janeiro: Companhia de Bolso, 2007.

TAWADA, Yôko. Bioskoop der Nacht. In: Überseezungen. Tübingen: Claudia Gehrke, 2002a, pp. 61-91.

TAWADA, Yôko. Überseezungen. Tübingen: Claudia Gehrke, 20ozb.

TAWADA, Yôko. Ekusofonii: bogo no soto e deru tabi [エクソフォニー —— 母語の外 へ出る旅J. Tóquio: Iwanami, 2003.

TAWADA, Yôko. Facing the bridge. Translated and with an Afterword by Margaret Mitsutani. Nova Iorque: New Directions, 2007a.

TAWADA, Yôko. Sprachpolizei und Spielpolyglotte. Tübingen: Claudia Gehrke, 2007b.

TAWADA, Yôko. Wo Europa anfängt E Ein Gast: Erzählungen und Gedichte. Tübingen: Konkursbuch, 2014.

TCHÉKHOV, Anton. Plays. Trad. Peter Carson. Londres: Penguin, 2002. 


\section{ANEXO}

\section{Poemas de Tawada Yôko' ${ }^{13}$}

\begin{tabular}{|c|c|c|}
\hline japonês & alemão & português \\
\hline 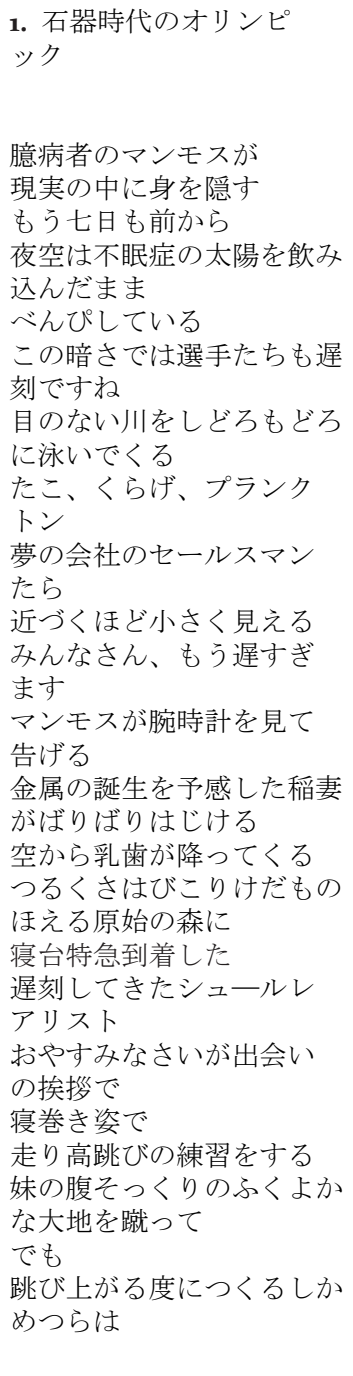 & $\begin{array}{l}\text { 1. Olympische Spiele der } \\
\text { Steinzeit } \\
\text { Das Mammut (der Feigling) } \\
\text { versteckt sich im Realen } \\
\text { sieben Tage schon leidet der } \\
\text { Nachthimmel } \\
\text { an Verstopfung } \\
\text { seit er die von Schlaflosigkeit } \\
\text { gequälte } \\
\text { Sonne verschluckt hat } \\
\text { die Olympioniken verspäten } \\
\text { sich } \\
\text { (wegen der Dunkelheit) } \\
\text { ziellos schwimmen im blinden } \\
\text { Fluss } \\
\text { Oktopus, Qualle und Plankton } \\
\text { die Handlungsreisenden der } \\
\text { Traumfirma } \\
\text { sehen kleiner aus je näher sie } \\
\text { kommen } \\
\text { es ist schon zu spät! gibt das } \\
\text { Mammut } \\
\text { nach einem Blick } \\
\text { auf die Armbanduhr bekannt } \\
\text { klirrend zerplatzt ein Blitz } \\
\text { der die Geburt des Metalls } \\
\text { vorhergesehen hatte } \\
\text { Milchzähne regnen vom } \\
\text { Himmel } \\
\text { im Urwald } \\
\text { wo Schlinggewächse wuchern } \\
\text { und Bestien brüllen } \\
\text { ist der Schlafwagenexpress } \\
\text { eingetroffen } \\
\text { der verspätete Surrealist ab- } \\
\text { solviert } \\
\text { im Nachthemd sein Lauf- und } \\
\text { Sprungtraining } \\
\text { er begrüßt jeden mit: Ruhen } \\
\text { Sie wohl! }\end{array}$ & $\begin{array}{l}\text { 1. Olimpíadas da Idade da Pe- } \\
\text { dra } \\
\text { o mamute covarde } \\
\text { esconde-se na realidade } \\
\text { há mais de sete dias } \\
\text { o céu noturno sofre } \\
\text { de prisão de ventre } \\
\text { porque engoliu o sol insone } \\
\text { com o céu tão escuro } \\
\text { os atletas se atrasaram } \\
\text { nadam à deriva no rio sem olhos } \\
\text { polvo, água-viva e plâncton } \\
\text { os caixeiros viajantes da empresa } \\
\text { de sonhos } \\
\text { quanto mais se aproximam meno- } \\
\text { res parecem } \\
\text { senhoras e senhores, é tarde de- } \\
\text { mais! } \\
\text { anuncia o mamute ao olhar } \\
\text { o relógio de pulso } \\
\text { estouram vibrantes os relâmpagos } \\
\text { prenunciando o nascimento dos } \\
\text { metais } \\
\text { dentes-de-leite chovem dos céus } \\
\text { na floresta primitiva onde videiras } \\
\text { crescem e feras rugem } \\
\text { chegou o trem noturno } \\
\text { um surrealista atrasado } \\
\text { deseja um "bom descanso" a todos } \\
\text { e treina de pijama } \\
\text { salto em altura chuta } \\
\text { a Terra tão redonda quanto o } \\
\text { ventre da irmã } \\
\text { no entanto } \\
\text { a cada salto nas alturas ele faz uma } \\
\text { careta e pensa } \\
\text { "os atletas parecem gênios da } \\
\text { poesia” }\end{array}$ \\
\hline
\end{tabular}

13 Fonte dos textos em alemão e japonês: TAWADA, Yoko. Wo Europa anfängt E Ein Gast: Erzählungen und Gedichte. Tübingen: Konkursbuch Verlag, 2014. 


\begin{tabular}{|c|c|c|}
\hline 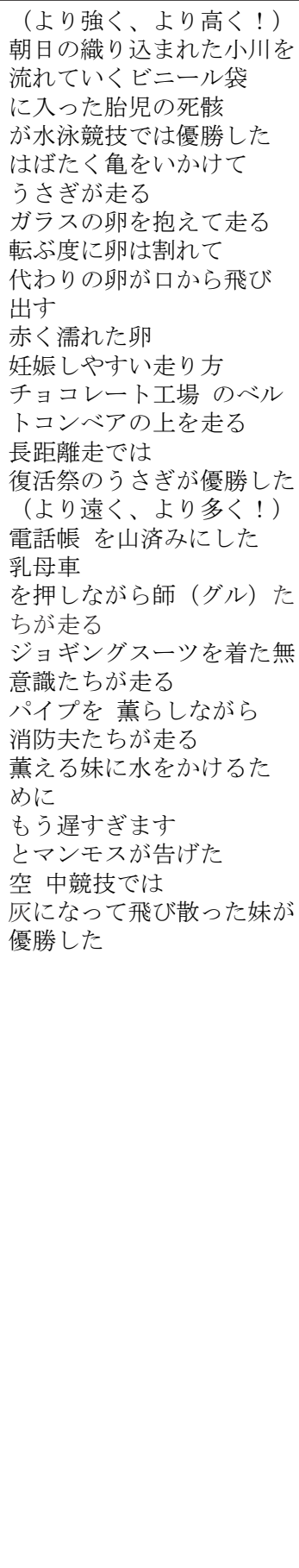 & $\begin{array}{l}\text { und tritt den Bauch der Erde } \\
\text { (so schön rund wie der seiner } \\
\text { Schwester) } \\
\text { bei jedem Sprung in die Höhe } \\
\text { aber } \\
\text { verrät sein vom Ernst verzerr- } \\
\text { tes Gesicht } \\
\text { doch den Sportler oder das } \\
\text { Genie } \\
\text { sie halten die Schildkröte } \\
\text { unter den Blitz } \\
\text { und lesen das Craquelé der } \\
\text { Gesetze: } \\
\text { nicht schlagen sondern } \\
\text { schmelzen } \\
\text { vor dem makellosen Plastik, } \\
\text { Feuer } \\
\text { zog sich die Steinzeit zurück } \\
\text { wenn aus dem Nabel der } \\
\text { schwangeren Schwester Fun- } \\
\text { ken sprühen } \\
\text { taut der Eiszeitwecker auf } \\
\text { und läutet } \\
\text { eine verfaulte Sonne rollt } \\
\text { aus dem Atomkraftwerk } \\
\text { (Stärker! Höher!) } \\
\text { im Schwimmwettbewerb siegte } \\
\text { der tote Embryo im Kunst- } \\
\text { stoffsack } \\
\text { der auf Gewebe aus Morgen- } \\
\text { licht } \\
\text { den kleinen Fluss herab getrie- } \\
\text { ben kam } \\
\text { das Kaninchen bedrängt im } \\
\text { Lauf } \\
\text { die flügelschlagende Schild- } \\
\text { kröte } \\
\text { immer wenn es fällt zerbricht } \\
\text { das gläserne } \\
\text { Ei das es in seinen Händen } \\
\text { trägt aber dann kommt ein } \\
\text { neues } \\
\text { Ei aus seinem Mund } \\
\text { herausgesprungen ein rotes } \\
\text { feuchtes } \\
\text { Ei (eine Laufart bei der man } \\
\text { leicht } \\
\text { schwanger wird) } \\
\text { beim Langstreckenlauf auf } \\
\text { dem Fließband } \\
\text { der Schokoladenfabrik } \\
\text { siegte der Osterhase } \\
\text { (Schneller! Mehr!) } \\
\text { die Gurus schieben im Lauf }\end{array}$ & $\begin{array}{l}\text { segura a tartaruga diante do rosto } \\
\text { para se proteger do relâmpago } \\
\text { nas rachaduras de seu casco se lê o } \\
\text { texto da lei } \\
\text { não mais lascar, fundir! } \\
\text { é o fim da idade da pedra } \\
\text { fogo! } \\
\text { devido ao plástico imaculado } \\
\text { saltam chamas do umbigo da irmã } \\
\text { grávida } \\
\text { que descongelam a era glacial e } \\
\text { derretem o despertador que come- } \\
\text { ça a tocar } \\
\text { de dentro da usina nuclear } \\
\text { vem rolando um sol podre } \\
\text { (mais forte! mais alto!) } \\
\text { em uma competição de natação } \\
\text { de fetos mortos em sacolas plás- } \\
\text { ticas } \\
\text { na superfície do rio tecida pela luz } \\
\text { matinal } \\
\text { um dos fetos vence } \\
\text { o coelho corre } \\
\text { e ultrapassa a tartaruga alada } \\
\text { o coelho corre } \\
\text { agarrado ao ovo de vidro } \\
\text { cada vez que ele tropeça o ovo } \\
\text { racha } \\
\text { cada vez que racha um ovo } \\
\text { salta de dentro da sua boca um } \\
\text { novo } \\
\text { ovo vermelho e úmido } \\
\text { é fácil engravidar assim correndo } \\
\text { o coelho da páscoa adentra a fábri- } \\
\text { ca de chocolates } \\
\text { e na esteira da linha de produção } \\
\text { corre } \\
\text { vence mais essa competição } \\
\text { de corrida de longa distância } \\
\text { (mais! e mais rápido!) } \\
\text { os gurus empurrando pilhas de } \\
\text { listas telefônicas } \\
\text { em carrinhos de bebê correm } \\
\text { os inconscientes em trajes esporti- } \\
\text { vos correm } \\
\text { os bombeiros fumando cachimbos } \\
\text { correm } \\
\text { e jogam água na irmã em chamas } \\
\text { mas já é tarde... é tarde demais... } \\
\text { anunciou o mamute } \\
\text { vence a corrida aérea } \\
\text { a irmã pulverizada em cinzas }\end{array}$ \\
\hline
\end{tabular}




\begin{tabular}{|c|c|c|}
\hline & $\begin{array}{l}\text { Berge } \\
\text { von Telefonbüchern im Kin- } \\
\text { derwagen vor sich her } \\
\text { die Unbewussten keuchen im } \\
\text { Joggingdress } \\
\text { die Feuerwehrleute (sie wollen } \\
\text { die brennende } \\
\text { Schwester löschen) saugen } \\
\text { im Trab } \\
\text { an den Schläuchen der Was- } \\
\text { serpfeifen } \\
\text { es ist zu spät! gab das Mam- } \\
\text { mut bekannt } \\
\text { deshalb siegte im Luftwett- } \\
\text { kampf } \\
\text { die zu Asche versprühte } \\
\text { Schwester }\end{array}$ & \\
\hline 2. ロンドンの目覚め & 2. Erwachen in London & 2. Despertar em Londres \\
\hline $\begin{array}{l}\text { 炎の傷口が閉じた振りする } \\
\text { 暗い舞台で } \\
\text { 九つ目五がビリヤードする } \\
\text { その夢にさわらずに } \\
\text { おはようを言わずに } \\
\text { 雨傘の言葉で断言する } \\
\text { 救われる必要なんてない } \\
\text { んだ、と }\end{array}$ & $\begin{array}{l}\text { Auf der dunklen Bühne die } \\
\text { so tut } \\
\text { als hätte die Flammenwunde } \\
\text { sich geschlossen } \\
\text { spielen neun Augenäpfel } \\
\text { Billard } \\
\text { Ohne den Traum zu berühren } \\
\text { ohne „guten Morgen“ zu sagen } \\
\text { versichere ich in der Sprache } \\
\text { des Regenschirms: } \\
\text { also die Notwendigkeit geret- } \\
\text { tet zu werden } \\
\text { besteht nicht }\end{array}$ & $\begin{array}{l}\text { no palco escuro que age como } \\
\text { se as feridas das chamas estives- } \\
\text { sem fechadas } \\
\text { há um jogo de bilhar com nove } \\
\text { globos oculares } \\
\text { sem tocar no sonho } \\
\text { sem dizer "bom dia" } \\
\text { na língua do guarda-chuva tu } \\
\text { declaras: } \\
\text { não há do que ser salva! }\end{array}$ \\
\hline $\begin{array}{l}\text { だって、ほら、 } \\
\text { からまわりするレコードの } \\
\text { 音のしずくが } \\
\text { あなたの鼓膜を打ち } \\
\text { 光のカレンダーが異国の眠 } \\
\text { りを横切る時 }\end{array}$ & $\begin{array}{l}\text { Ich habe es gewusst } \\
\text { die Tontropfen der leerlau- } \\
\text { fenden } \\
\text { Schallplatte schlagen } \\
\text { auf dein Trommelfell } \\
\text { wenn der Lichtkalender den } \\
\text { Schlaf } \\
\text { der Fremdländer durchquert }\end{array}$ & $\begin{array}{l}\text { afinal de contas } \\
\text { as gotas de som que caem do disco } \\
\text { terminado girando no vazio } \\
\text { continuam martelando no teu } \\
\text { tímpano } \\
\text { quando o calendário de luz } \\
\text { cruza o sono de um país estran- } \\
\text { geiro }\end{array}$ \\
\hline 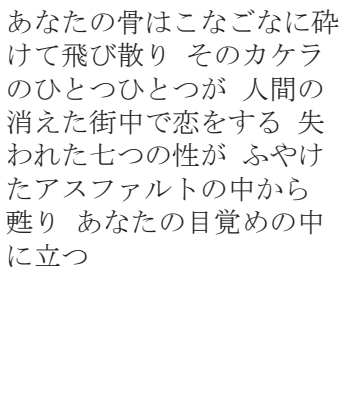 & $\begin{array}{l}\text { Die Späne deiner Knochen } \\
\text { fliegen auseinander } \\
\text { ihre Splitter verlieben sich } \\
\text { einer nach dem anderen } \\
\text { mitten auf den Straßen ohne } \\
\text { Menschen } \\
\text { Die verlorenen sieben Ge- } \\
\text { schlechter } \\
\text { kehren aus dem aufgeweichten } \\
\text { Asphalt zurück } \\
\text { und stehen mitten im Erwa- } \\
\text { chen }\end{array}$ & $\begin{array}{l}\text { os teus ossos se quebram em es- } \\
\text { tilhaços } \\
\text { que voam por todos os lados } \\
\text { e, um por um, apaixonam-se } \\
\text { no meio da rua deserta } \\
\text { os sete sexos perdidos } \\
\text { ressuscitam de dentro do asfalto } \\
\text { molhado } \\
\text { e se erguem dentro de teu des- } \\
\text { pertar }\end{array}$ \\
\hline
\end{tabular}




\begin{tabular}{|c|c|c|}
\hline $\begin{array}{l}\text { 3. 闘牛 } \\
\text { 首のもげた観客たちがここ } \\
\text { ぞと期待の拍手す } \\
\text { 陶器の空ばちばち割れそ } \\
\text { うな } \\
\text { アイスクリイム売りが溶 } \\
\text { けていく } \\
\text { 円形野外劇場の真ん中に横 } \\
\text { たわった } \\
\text { 上等のビフテキ } \\
\text { 二百グラム } \\
\text { つけあわせの薬っ葉（無農 } \\
\text { 薬）が夏風にそよぐ } \\
\text { 闘牛士は車椅子の子供だ } \\
\text { 子供は剣を振り上げ狙い } \\
\text { をつける } \\
\text { 剣が肉に当ると } \\
\text { ビフテキはあくびした } \\
\text { もう一度あたると } \\
\text { ビフテキがのんびり腰を } \\
\text { 上げ }\end{array}$ & $\begin{array}{l}\text { 3. Ein Stierkampf } \\
\text {,s ist soweit," klatschen im } \\
\text { Rausch der Erwartung } \\
\text { die Zuschauer mit den verlore- } \\
\text { nen Köpfen, } \\
\text { dass es die Keramikluft zer- } \\
\text { sprengen möchte. } \\
\text { Eine Eisverkäuferin schmilzt } \\
\text { dahin. } \\
\text { Mitten auf der kreisrunden } \\
\text { Freilichtbühne } \\
\text { hingestreckt } \\
\text { ein Beefsteak erster Qualität } \\
\text { 2oo Gramm. } \\
\text { Garniert mit Grünzeug (na- } \\
\text { turgedüngt), } \\
\text { mit Grünzeug, das flattert im } \\
\text { Sommerwind. } \\
\\
\text { Der Stierkämpfer ist: aufdem } \\
\text { Rollstuhl ein Kind, } \\
\text { - ob Junge oder Mädchen, das } \\
\text { weiß man nicht, } \\
\text { weil: } \\
\text { es versteckt seine Nase- } \\
\text { es hebt und schwingt sein } \\
\text { Schwert und zielt. } \\
\text { Das Schwert dringt ein ins } \\
\text { Fleisch, } \\
\text { das Beefsteak gähnt, } \\
\text { beim nächsten Treffer erhebt } \\
\text { es heiter die Hüfte } \\
\text { beim dritten } \\
\text { sprießen ihm Hörner, jetzt ist } \\
\text { es ein Stier. } \\
\text { Ein fadenscheiniger weißer } \\
\text { knochiger Stier. } \\
\text { Ein Senfblütenkranz baumelt } \\
\text { von seinem Hals. } \\
\text { Er macht sich torkelnd auf den } \\
\text { Heimweg. } \\
\text { In Richtung } \\
\text { Ganges. }\end{array}$ & $\begin{array}{l}\text { 3. Tourada } \\
\text { os espectadores de cabeças arran- } \\
\text { cadas aplaudem } \\
\text { é chegada a hora } \\
\text { o vazio da cerâmica está a ponto } \\
\text { de quebrar } \\
\text { o vendedor de sorvete está derre- } \\
\text { tendo } \\
\text { estendido no meio da praça de } \\
\text { touros } \\
\text { um bife de filé mignon } \\
\text { de } 200 \text { gramas } \\
\text { guarnecido de ervas (sem agro- } \\
\text { tóxico) } \\
\text { o toureiro é a criança da cadeira } \\
\text { de rodas } \\
\text { que ergue a espada apontando } \\
\text { para o alvo } \\
\text { e penetra na carne } \\
\text { o bife bocejou } \\
\text { e de novo } \\
\text { o bife descansadamente se levanta } \\
\text { na terceira vez } \\
\text { despontam cifres, agora é um } \\
\text { touro } \\
\text { um touro branco com ossos des- } \\
\text { botados } \\
\text { com uma coroa de flores de mos- } \\
\text { tarda balançando } \\
\text { em seu pescoço } \\
\text { cambaleante, ele volta para casa } \\
\text { em direção ao rio Ganges }\end{array}$ \\
\hline
\end{tabular}




\begin{tabular}{|c|c|c|}
\hline 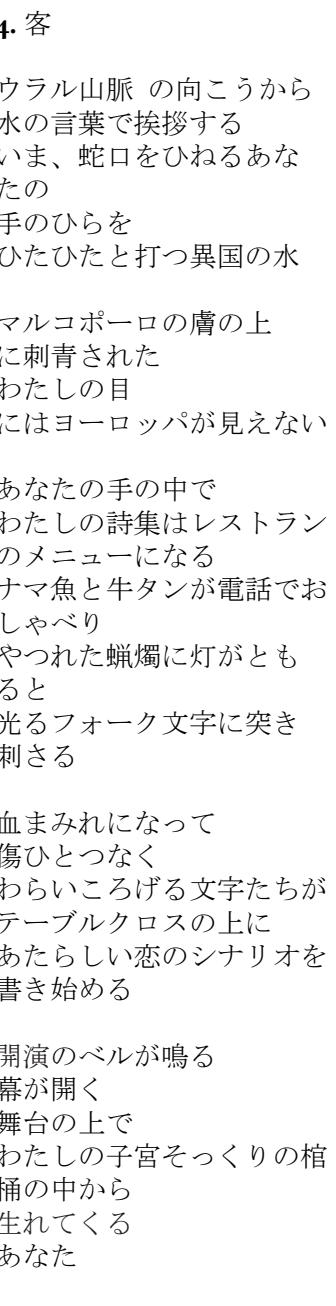 & $\begin{array}{l}\text { 4. Ein Gast } \\
\text { Von jenseits des Urals her } \\
\text { grüßt es in der Sprache des } \\
\text { Wassers } \\
\text { Du drehst am Hahn } \\
\text { und es rinnt jetzt in deine } \\
\text { Hand } \\
\text { das Wasser eines fremden } \\
\text { Landes } \\
\text { Mein in Marco Polo eintäto- } \\
\text { wiertes Auge } \\
\text { kann Europa nicht sehen } \\
\\
\text { In deiner Hand } \\
\text { wird meine Gedichtsammlung } \\
\text { eine Speisekarte } \\
\text { Roher Fisch und Rinderzunge } \\
\text { führen ein Telefongespräch } \\
\text { Zünde ich die magere Kerze an } \\
\text { sticht eine leuchtende Gabel in } \\
\text { die Lettern } \\
\text { Blutverschmiert } \\
\text { und ohne Wunde } \\
\text { krümmen sich die Lettern vor } \\
\text { Lachen } \\
\text { und buchstabieren auf der } \\
\text { Tischdecke } \\
\text { ein neues Liebesszenario } \\
\text { Die Klingel ruft Der Vorhang } \\
\text { öffnet sich } \\
\text { Aufder Bühne aus einem } \\
\text { Sarkophag } \\
\text { der ganz meiner Gebärmutter } \\
\text { gleicht } \\
\text { wirst du geboren }\end{array}$ & $\begin{array}{l}\text { 4. Hóspede } \\
\text { do outro lado dos Urais } \\
\text { vem um olá na língua da água } \\
\text { você abre a torneira } \\
\text { e agora corre em suas mãos } \\
\text { a água de uma terra estrangeira } \\
\text { sobre a pele de Marco Polo } \\
\text { estão tatuados } \\
\text { os meus olhos } \\
\text { que não conseguem avistar a } \\
\text { Europa } \\
\text { em sua mão minha coletânea } \\
\text { de poemas vira um cardápio } \\
\text { peixe cru e língua de boi } \\
\text { conversam por telefone } \\
\text { um garfo reluzente espeta as letras } \\
\text { à luz da vela que arde gasta } \\
\text { manchadas de sangue e sem ferida } \\
\text { as letras se contorcem de rir } \\
\text { e soletram na toalha de mesa } \\
\text { um novo roteiro de amor } \\
\text { o sinal que anuncia o começo da } \\
\text { peça toca } \\
\text { as cortinas se abrem } \\
\text { sobre o palco, } \\
\text { de um sarcófago } \\
\text { igualzinho ao meu útero } \\
\text { nasce } \\
\text { você }\end{array}$ \\
\hline
\end{tabular}




\begin{tabular}{|c|c|c|}
\hline $\begin{array}{l}\text { 犯人は誰 } \\
\text { 小川に浮かぶ足跡を } \\
\text { からすの影がついばむ } \\
\text { うつぶせに倒れていたはず } \\
\text { のあなたは } \\
\text { 血痕ひとつ残さず消え去り } \\
\text { 公共団地のすみやかな歯 } \\
\text { 並び } \\
\text { 礼儀正しい強姦 } \\
\\
\text { やっちまったね } \\
\text { 空になく土に埋もれず } \\
\text { 風の中にもにおってこない }\end{array}$ & $\begin{array}{l}\text { 5. Eine Rückkehr } \\
\text { Wenn man mit einem Ham- } \\
\text { mer } \\
\text { auf die Pupille der Finsternis } \\
\text { schlägt } \\
\text { springen aus dem Kürbis } \\
\text { plötzlich hervor } \\
\text { ein Ringfinger } \\
\text { und Aschenbrödels Fußknö- } \\
\text { chel } \\
\text { die in den Stöckelschuhen } \\
\text { vergessen worden waren } \\
\\
\text { Wer war der Täter? } \\
\text { Die Schatten der Raben } \\
\text { picken nach den Fußspuren } \\
\text { die auf kleinen Flüssen treiben } \\
\text { Die flach auf dem Bauch lie- } \\
\text { gen sollte: Du } \\
\text { bist verschwunden ohne eine } \\
\text { einzige Blutspur } \\
\text { Das flinke Gebiss der Sied- } \\
\text { lungen } \\
\text { Die manierliche Vergewalti- } \\
\text { gung } \\
\text { Das wär erledigt } \\
\text { Nicht in der Luft } \\
\text { Nicht in der Erde begraben } \\
\text { Nicht einmal ein Geruch im } \\
\text { Wind } \\
\text { Hände und Füße abgeschnit- } \\
\text { ten } \\
\text { der Rumpf herausgezogen } \\
\text { Der Kopf geraubt } \\
\text { Umgeben von soviel Zärtlich- } \\
\text { keit } \\
\text { Ganz ohne Tränen } \\
\text { Ihr Stöhnen gleitet über den } \\
\text { Messerrücken } \\
\text { Im Haushaltsbuch erheben } \\
\text { sich die Toten } \\
\text { Zum Beispiel } \\
\text { diese zufällig falsch geschrie- } \\
\text { bene Zahl } \\
\text { trägt die ganze Sprache der } \\
\text { Liebe } \\
\text { aufihrer Schulter } \\
\text { Wenn sie auffliegt } \\
\text { werden wir ihre Füße packen }\end{array}$ & $\begin{array}{l}\text { 5. O retorno } \\
\text { batendo com um martelo } \\
\text { as pupilas da escuridão } \\
\text { a abóbora explode e saem voando } \\
\text { pedaços da Cinderela } \\
\text { um dedo anelar, um tornozelo } \\
\text { esquecido junto a um sapato de } \\
\text { salto } \\
\text { quem foi o criminoso? } \\
\text { as sombras dos corvos } \\
\text { bicam as pegadas } \\
\text { que flutuam nos riachos } \\
\text { você deveria ter caído de cara no } \\
\text { chão } \\
\text { mas você sumiu sem deixar uma } \\
\text { mancha de sangue } \\
\text { a veloz dentadura dos prédios de } \\
\text { apartamentos populares } \\
\text { era só o que me faltava! } \\
\text { nada no ar } \\
\text { nada enterrado } \\
\text { nada, nem mesmo um cheiro no } \\
\text { ar } \\
\text { mãos e pés cortados } \\
\text { o tronco arrancado } \\
\text { a cabeça inteira roubada } \\
\text { cercada por tanta ternura } \\
\text { sem lágrimas } \\
\text { seus gemidos deslizam pelo dorso } \\
\text { da faca } \\
\text { no livro de contabilidade domésti- } \\
\text { ca os mortos se levantam } \\
\text { quando } \\
\text { a agenda do vidente } \\
\text { que imita o mundo der um salto } \\
\text { agarre-a! } \\
\text { esses números sem querer escritos } \\
\text { errados } \\
\text { forem saltar carregando nas costas } \\
\text { as palavras de amor } \\
\text { agarre-os pelos pés! } \\
\text { a }\end{array}$ \\
\hline
\end{tabular}


Remate de Males, Campinas-SP, v.38, n.2, pp. 791-826, jul./dez. 2018 - 815

\begin{tabular}{|c|c|c|}
\hline $\begin{array}{l}\text { 囚人たちが } \\
\text { カレンダーをかかえて帰 } \\
\text { ってくる } \\
\text { とびかう石つぶては指輪 } \\
\text { に変わり } \\
\text { からからとぶつかりながら } \\
\text { 葬式の朝をほのかに照らす } \\
\text { 囚人たちが帰ってくる }\end{array}$ & $\begin{array}{l}\text { Werden wir nach dem Notiz- } \\
\text { buch } \\
\text { des Wahrsagers greifen } \\
\text { das aufgeflogen ist nach dem } \\
\text { Vorbild der Welt } \\
\\
\text { Die Gefangenen kommen } \\
\text { mit Kalendern unter den Ar- } \\
\text { men zurück } \\
\text { Die umherfliegenden Kiesel } \\
\text { verwandeln sich in Ringe } \\
\text { die zart den Morgen der Beer- } \\
\text { digung beleuchten } \\
\text { Die Gefangenen kommen } \\
\text { zurück }\end{array}$ & $\begin{array}{l}\text { os prisioneiros estão voltando } \\
\text { com calendários debaixo dos } \\
\text { braços } \\
\text { os seixos que voam por todos os } \\
\text { lados } \\
\text { transformam-se em anéis } \\
\text { brilhando tênues na manhã do } \\
\text { funeral } \\
\text { os prisioneiros estão voltando }\end{array}$ \\
\hline
\end{tabular}




\begin{tabular}{|c|c|c|}
\hline 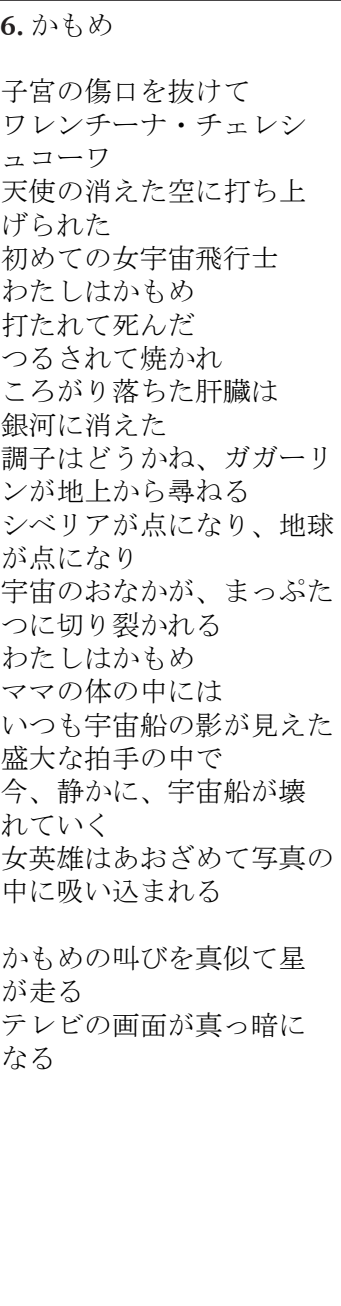 & $\begin{array}{l}\text { 6. Möwe } \\
\text { Durch die Wände der Gebär- } \\
\text { mutter hindurch } \\
\text { wurde Walentina Tereschkowa } \\
\text { in den Himmel geschossen } \\
\text { wo keine Engel mehr sind } \\
\text { Der erste weibliche Kosmo- } \\
\text { naut } \\
\quad \text { Ich bin eine Möwe } \\
\quad \text { und starb unter Beschuss } \\
\quad \text { war aufgehängt und bin } \\
\text { verbrannt } \\
\quad \text { Die herabgestürzte Leber } \\
\quad \text { ist in der Milchstraße ver- } \\
\text { schwunden } \\
\text { Wie fühlst du dich? } \\
\text { fragt Gagarin von der Erde aus } \\
\text { Sibirien ist ein Punkt Die } \\
\text { Erdkugel ist ein Punkt } \\
\text { Der Bauch des Kosmos reißt } \\
\text { mitten entzwei } \\
\quad \text { ich bin eine Möwe } \\
\quad \text { im Körper der Mutter } \\
\quad \text { konnte ich immer den } \\
\text { Schatten } \\
\quad \text { eines Raumschiffs sehen } \\
\text { Unter gewaltigem Applaus } \\
\text { zerbirst jetzt } \\
\text { still das Raumschiff Die Hel- } \\
\text { din wird erbleichend } \\
\text { in eine Fotografie hineinge- } \\
\text { weht } \\
\text { Die Sterne rennen und ahmen } \\
\text { den Schrei } \\
\text { der Möwe nach } \\
\text { Der Monitor wird raben- } \\
\text { schwarz }\end{array}$ & $\begin{array}{l}\text { 6. Gaivota } \\
\text { escapa da ferida do útero } \\
\text { Valentina Tereshkova } \\
\text { que foi lançada aos céus } \\
\text { onde não há mais anjos } \\
\text { a primeira mulher astronauta } \\
\text { eu sou uma gaivota } \\
\text { atingida e morta } \\
\text { queimada na forca } \\
\text { o fígado pendurado } \\
\text { desapareceu na Via-Láctea } \\
\text { como você se sente? } \\
\text { Gagarin pergunta da terra } \\
\text { a Sibéria se torna um ponto } \\
\text { o globo terrestre se torna um } \\
\text { ponto } \\
\text { a barriga do cosmo se rasga ao } \\
\text { meio } \\
\text { eu sou uma gaivota } \\
\text { no corpo da mãe } \\
\text { eu sempre vi a sombra } \\
\text { de uma nave espacial } \\
\text { sob intensos aplausos agora ex- } \\
\text { plode } \\
\text { em silêncio, a nave espacial } \\
\text { a heroína se torna pálida } \\
\text { ao ser sugada para dentro da fo- } \\
\text { tografia } \\
\text { TV escurece totalmente } \\
\text { as estrelas seguem seu curso imi- } \\
\text { Tando o grito da gaivota da }\end{array}$ \\
\hline
\end{tabular}




\begin{tabular}{|c|c|c|}
\hline $\begin{array}{l}\text { 7. 黒鍵 } \\
\text { 昨日、動詞がひとつ死ん } \\
\text { だが } \\
\text { 誰も気づかなかった } \\
\text { 見せかけの野蛮人と呼ば } \\
\text { れて } \\
\text { わたしは台所でピアノを } \\
\text { 弾く } \\
\text { じれふあしれそ } \\
\text { 戦馬のどす黒い血が黒鍵 } \\
\text { をつたって } \\
\text { 指先から、のぼってくる } \\
\text { 見えないものだけが } \\
\text { わたしたちを人殺しに変 } \\
\text { えていく } \\
\text { アルファべットが盲目の } \\
\text { まま } \\
\text { わたしの体内を散歩する } \\
\text { じれふあしれそ } \\
\text { 舌を革打つ句読点 } \\
\text { 除苟はいつも明日始まる }\end{array}$ & $\begin{array}{l}\text { 7. Schwarze Tasten } \\
\text { Gestern ist ein Verb gestorben } \\
\text { niemand hat es bemerkt } \\
\text { Sie nennen mich einen der } \\
\text { vorgibt } \\
\text { ein Barbar zu sein } \\
\text { Ich spiele in der Küche Klavier } \\
\text { do re fa ti re so } \\
\text { Des Schlachtrosses schwärzli- } \\
\text { ches Blut } \\
\text { läuft über die Tastatur } \\
\text { und klettert über die Finger- } \\
\text { spitzen hoch } \\
\text { Nur die unsichtbaren Dinge } \\
\text { verwandeln uns in Mörder } \\
\text { das Alphabet wird blind } \\
\text { und spaziert durch meinen } \\
\text { Körper } \\
\text { do re fa ti re so } \\
\text { Die Interpunktionen die auf } \\
\text { der Zunge trommeln } \\
\text { Das Massaker beginnt immer } \\
\text { morgen }\end{array}$ & $\begin{array}{l}\text { 7. Teclas pretas } \\
\text { ontem morreu um verbo } \\
\text { mas ninguém notou } \\
\text { eu, que sou acusada de ser uma } \\
\text { falsa bárbara } \\
\text { toco piano na cozinha } \\
\text { dó ré fá si ré sol } \\
\text { o sangue negro do cavalo de ba- } \\
\text { talha } \\
\text { corre por cima das teclas pretas } \\
\text { e sobe pelas pontas dos dedos } \\
\text { apenas as coisas invisíveis } \\
\text { transformam-nos em assassinos } \\
\text { o alfabeto permanece cego } \\
\text { e passeia pelo meu corpo } \\
\text { dó ré fá si ré sol } \\
\text { o ritmo da pontuação que toca a } \\
\text { língua como um tambor } \\
\text { o massacre começa sempre ama- } \\
\text { nhã }\end{array}$ \\
\hline
\end{tabular}




\begin{tabular}{|c|c|c|}
\hline 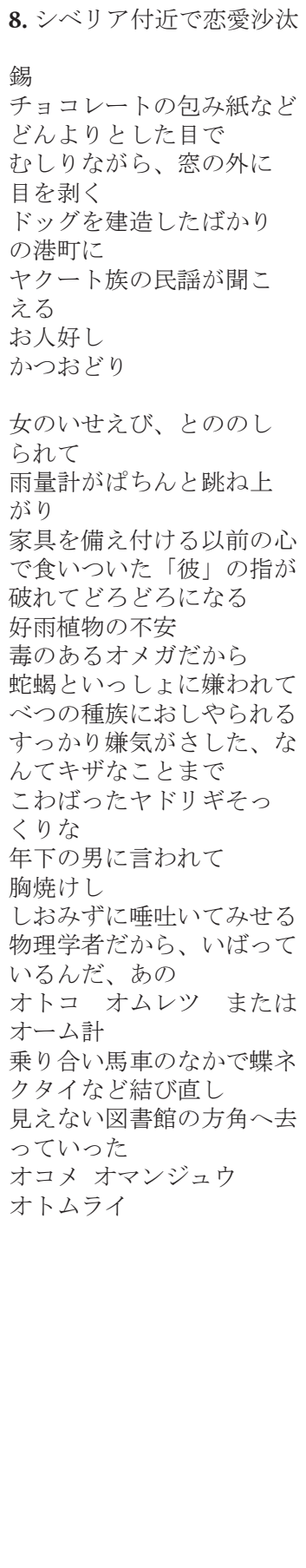 & $\begin{array}{l}\text { 8. Eine Liebesaffäre in der } \\
\text { Nähe Sibiriens } \\
\\
\text { Das Zinn } \\
\text { das Schokoladenpapier und } \\
\text { so weiter } \\
\text { dunkelen Auges } \\
\text { rupfend, späh' ich aus dem } \\
\text { Fenster } \\
\text { In der Hafenstadt mit dem } \\
\text { frisch errichteten Dock } \\
\text { erklingen die Lieder der Ja- } \\
\text { kuten } \\
\text { Einfaltspinsel } \\
\text { Bonitovogel } \\
\text { Langustenweibchen } \\
\text { ward ich gescholten } \\
\\
\text { Die Regenwaage federt klir- } \\
\text { rend hoch } \\
\text { „Sein“ Finger, in den ich mit } \\
\text { noch } \\
\text { unmöbliertem Herzen } \\
\text { gebissen hatte, geht kaputt, } \\
\text { wird ganz breiig. } \\
\text { Unruhe unter meinen hydro- } \\
\text { philen Pflanzen. } \\
\text { Ich bin nämlich ein giftiges } \\
\text { Omega. } \\
\text { Man hasst mich wie Schlan- } \\
\text { gen und Skorpione. } \\
\text { Und rechnet mich einer beson- } \\
\text { deren Spezies zu. } \\
\\
\text { Wie ekelig! sagt mir mit geüb- } \\
\text { ter Affektiertheit } \\
\text { ein junger Mann } \\
\text { so steif wie eine Mistel. } \\
\text { Ich habe Sodbrennen, } \\
\text { zeige, wie man in Brackwasser } \\
\text { spuckt. } \\
\text { Physiker! Daher Angeber. } \\
\text { O Mann, Omelett oder } \\
\text { Ohm-Messer. } \\
\text { Im Omnibus richtet er seinen } \\
\text { Schmetterlingsbinder } \\
\text { und verschwindet in einer } \\
\text { unsichtbaren Bibliothek. } \\
\text { O Reis, o Knödel. } \\
\text { O Beerdigung. }\end{array}$ & $\begin{array}{l}\text { 8. Um caso de amor nos arredo- } \\
\text { res da Sibéria } \\
\text { latas } \\
\text { papéis de chocolate etc. } \\
\text { enquanto colho tudo do chão } \\
\text { com meus olhos escuros espio } \\
\text { pela janela } \\
\text { na cidade portuária com a doca } \\
\text { recém-construída } \\
\text { ecoam os sons dos cantos do povo } \\
\text { iacuto } \\
\text { boba } \\
\text { mergulhão } \\
\text { lagosta fêmea } \\
\text { era como me xingavam } \\
\text { o pluviômetro dispara com um } \\
\text { som metálico } \\
\text { o dedo do meu namorado que eu } \\
\text { arranquei com os dentes } \\
\text { quando eu ainda tinha o coração } \\
\text { desmobiliado } \\
\text { amoleceu e se desfez } \\
\text { angústia das plantas da estação } \\
\text { da chuva } \\
\text { na verdade eu sou um ômega } \\
\text { venenoso } \\
\text { odeiam-me como a cobras e es- } \\
\text { corpiões } \\
\text { e me categorizam como uma } \\
\text { espécie especial } \\
\text { que nojo! diz-me com ensaiada } \\
\text { afetação } \\
\text { um jovem } \\
\text { duro como um visco } \\
\text { eu tenho azia } \\
\text { mostre como cuspir em água } \\
\text { salgada } \\
\text { físico! por isso pretensioso. } \\
\text { homem omelete ou ainda } \\
\text { ohmímetro } \\
\text { no ônibus, ele arruma sua gravata } \\
\text { borboleta } \\
\text { e desaparece em direção a uma } \\
\text { biblioteca invisível. } \\
\text { orégano ovo de páscoa } \\
\text { homilia }\end{array}$ \\
\hline
\end{tabular}




\begin{tabular}{|c|c|c|}
\hline $\begin{array}{l}\text { 9. 二十一世紀の手まわし } \\
\text { オルガン } \\
\text { 夜空に大観覧車が浮かび } \\
\text { 上がる } \\
\text { 部長がソセージを食って } \\
\text { いる } \\
\text { 食い終わると自分の親指に } \\
\text { 食いつ } \\
\text { 手のひらにむしゃぶりつき } \\
\text { 腕も噛みくだいて肩から } \\
\text { 胸へ } \\
\text { とうとう全部食い尽くして } \\
\text { 後には性器だけ残った } \\
\\
\text { 埃にまみれて忘れられた } \\
\text { 性器から } \\
\text { 女のからだが伸びる } \\
\text { 腹から乳房へ、首から頭へ } \\
\text { ただ耳だけが忘れた } \\
\text { 大観覧車がまわる } \\
\text { 母がお月様を食っている } \\
\text { 色から骨へ } \\
\text { 肉からリズムへ } \\
\text { 全部食い終わると } \\
\text { 後には何も残らなかった }\end{array}$ & $\begin{array}{l}\text { 9. Eine Drehorgel aus dem } \\
\text { 21. Jahrhundert } \\
\text { Am Abendhimmel schwebt ein } \\
\text { Riesenrad } \\
\text { Der Abteilungsleiter kaut an } \\
\text { einer Wurst } \\
\text { Als er sie aufgegessen hat } \\
\text { verschlingt er seinen Daumen } \\
\text { stürzt sich auf die Hand und } \\
\text { nagt auch seinen Arm hinweg } \\
\text { und frisst von der Schulter } \\
\text { bis zur Brust schließlich alles } \\
\text { auf } \\
\text { Nur das Geschlechtsorgan } \\
\text { bleibt übrig } \\
\text { Aus dem staubigen vergesse- } \\
\text { nen Organ } \\
\text { reckt sich ein Frauenleib } \\
\text { vom Bauch bis zu den Brust- } \\
\text { spitzen } \\
\text { vom Hals bis zum Kopf } \\
\text { nur das Ohr vergaß zu wach- } \\
\text { sen } \\
\text { Das Riesenrad es dreht sich } \\
\text { Die Mutter verzehrt den Mond } \\
\text { von der Farbe bis zu den Kno- } \\
\text { chen } \\
\text { vom Fleisch bis zum Rhyth- } \\
\text { mus } \\
\text { als sie fertig ist } \\
\text { ist nichts mehr da }\end{array}$ & $\begin{array}{l}\text { 9. O realejo do século XXI } \\
\text { paira no céu da noite uma roda } \\
\text { gigante } \\
\text { o chefe come uma salsicha } \\
\text { quando termina de comê-la } \\
\text { come o próprio polegar } \\
\text { avança em sua mão } \\
\text { rói o braço todo } \\
\text { devora desde o ombro } \\
\text { o peito, o corpo todo até o fim } \\
\text { sobra apenas o órgão genital } \\
\text { do órgão empoeirado e esquecido } \\
\text { cresce um corpo de mulher } \\
\text { da barriga aos mamilos, do pesco- } \\
\text { ço à cabeça } \\
\text { apenas as orelhas esqueceram de } \\
\text { crescer } \\
\text { a roda gigante gira } \\
\text { a mãe come a lua } \\
\text { desde a cor até os ossos } \\
\text { da carne ao ritmo } \\
\text { quando ela termina } \\
\text { já não há mais nada }\end{array}$ \\
\hline
\end{tabular}




\begin{tabular}{|c|c|c|}
\hline 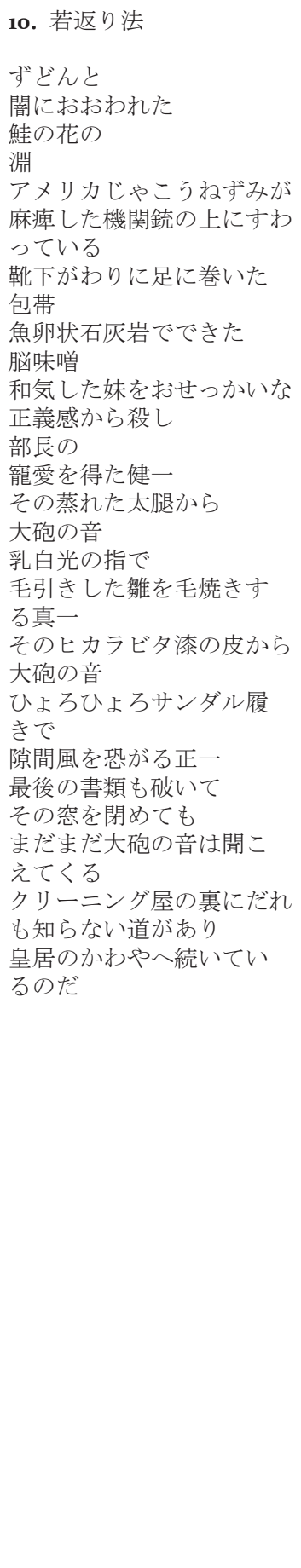 & $\begin{array}{l}\text { 1o. Eine Verjüngungsme- } \\
\text { thode } \\
\text { Mit einem Plumps! } \\
\text { von Dunkelheit erfüllt: } \\
\text { der Lachsblüten-Schlund } \\
\text { Eine amerikanische Bisam- } \\
\text { ratte } \\
\text { hockt auf einem gelähmten } \\
\text { Maschinengewehr } \\
\text { Bandagen statt der Strümpfe } \\
\text { um seine Füß' } \\
\text { Ein Hirn aus Kalkstein in } \\
\text { Fischlaichkonsistenz } \\
\text { der war der Starke genannt } \\
\text { Anständigkeit hieß ihn die } \\
\text { Schwester morden } \\
\text { denn sie hatte fehlgetreten } \\
\text { und sein Chef hat ihn geliebt } \\
\text { Aus seinen schimmelnden } \\
\text { Schenkeln } \\
\text { dröhnt es wie von Kanonen } \\
\text { Der war der Wahrhaftige } \\
\text { genannt } \\
\text { Mit milchkorallweissen Fin- } \\
\text { gern hatte er } \\
\text { Hühner gerupft und Federn } \\
\text { verbrannt } \\
\text { Aus der verdörrten Haut sei- } \\
\text { ner Knie } \\
\text { dröhnt es wie von Kanonen } \\
\text { Der war der Aufrechte ge- } \\
\text { Hinter der Reinigung gibts } \\
\text { eine Straße } \\
\text { die niemand kennt } \\
\text { die führt zum kaiserlichen } \\
\text { Abort } \\
\text { Auf Sandalen ging er schwan- } \\
\text { kend } \\
\text { und ängstigte sich vor Zugluft } \\
\text { Und immer } \\
\text { dröhnt es wie von Kanonen } \\
\text { auch wenn vernichtet die } \\
\text { letzte Akte } \\
\text { und geschlossen die Fenster } \\
\text { and }\end{array}$ & $\begin{array}{l}\text { 10. Um método de rejuvenesci- } \\
\text { mento } \\
\text { som da queda } \\
\text { cheio de escuridão } \\
\text { o abismo da flor-de-salmão } \\
\text { um rato-almiscareiro americano } \\
\text { abaixa-se atrás de uma metralha- } \\
\text { dora dormente } \\
\text { em seus pés, ataduras no lugar de } \\
\text { meias } \\
\text { miolos de calcário com a consis- } \\
\text { tência de ovas de peixe } \\
\text { este era chamado "O Forte" } \\
\text { a honra o obrigou a assassinar sua } \\
\text { irmã tão plácida } \\
\text { ele que era tão amado de seu chefe } \\
\text { de suas coxas mofadas } \\
\text { o som dos canhões } \\
\text { este era chamado “O Verdadeiro" } \\
\text { com dedos translúcidos e leitosos } \\
\text { ele } \\
\text { depenava galinhas e queimava as } \\
\text { penas } \\
\text { da pele ressecada de seus joelhos } \\
\text { o som dos canhões } \\
\text { este era chamado “O Correto" } \\
\text { vinha trôpego em suas sandálias } \\
\text { e se assustava com as correntes } \\
\text { de ar } \\
\text { mesmo destruindo o último docu- } \\
\text { mento e fechando a janela } \\
\text { ainda assim } \\
\text { o som dos canhões } \\
\text { qua fundos da lavanderia há uma } \\
\text { essa rua leva à latrina do Palácio } \\
\text { Imperial }\end{array}$ \\
\hline
\end{tabular}




\begin{tabular}{|c|c|c|}
\hline $\begin{array}{l}\text { 11. 約束の庭 } \\
\text { あなた } \\
\text { タイプライターの中の聴聞 } \\
\text { 僧とばかり話している } \\
\text { 今夜 } \\
\text { スープ血の中から } \\
\text { 手のひらが一枚浮かび上 } \\
\text { がり } \\
\text { あなたの額に話しかける } \\
\text { その時、額の痛むのは } \\
\text { 脳ミソの傷口から } \\
\text { 桃の木が一本、伸びるから } \\
\text { あなたの血を吸い上げて } \\
\text { 輝き熟れる桃の実の } \\
\text { こまやかなドが奇ってく } \\
\text { るミツバチのくちびるに } \\
\text { 痛い } \\
\text { 桃の実ひとつ } \\
\text { 熟れすぎて } \\
\text { チェス盤の上にぼとり落 } \\
\text { ちる }\end{array}$ & $\begin{array}{l}\text { 11. Der verabredete Garten } \\
\text { Du } \\
\text { sprichst nur mit dem Prediger } \\
\text { in der Schreibmaschine } \\
\text { Heute abend } \\
\text { greift aus dem Suppenteller } \\
\text { eine Hand } \\
\text { um mit deiner Stirn zu spre- } \\
\text { chen } \\
\text { Der Kopfschmerz den du dann } \\
\text { verspürst } \\
\text { stammt von der Wunde her } \\
\text { im Hirn } \\
\text { aus der ein Pfirsichbaum sich } \\
\text { streckt } \\
\text { und dein Blut nach oben saugt } \\
\text { die zärtlichen Dornen } \\
\text { der reifeglänzenden Pfirsich- } \\
\text { früchte } \\
\text { tun den Lippen der Bienen die } \\
\text { sich nähern } \\
\text { weh } \\
\text { Ein überreifer } \\
\text { Pfirsich } \\
\text { fällt dumpf auf ein Schach- } \\
\text { brett }\end{array}$ & $\begin{array}{l}\text { 11. O jardim do encontro } \\
\text { tu } \\
\text { só falas com teu confessor } \\
\text { que vive dentro da máquina de } \\
\text { escrever } \\
\text { hoje à noite } \\
\text { sai do prato de sopa } \\
\text { uma mão } \\
\text { para falar com a tua testa } \\
\text { a dor de cabeça que tu então } \\
\text { sentes } \\
\text { vem da ferida no cérebro } \\
\text { da qual se ergue um pessegueiro } \\
\text { que suga o teu sangue para cima } \\
\text { os minúsculos espinhos } \\
\text { dos brilhantes pêssegos maduros } \\
\text { fazem os lábios das abelhas que se } \\
\text { aproximam } \\
\text { doerem } \\
\text { maduro demais, um } \\
\text { pêssego } \\
\text { cai com um som abafado no tabu- } \\
\text { leiro de xadrez }\end{array}$ \\
\hline
\end{tabular}




\begin{tabular}{|c|c|c|}
\hline 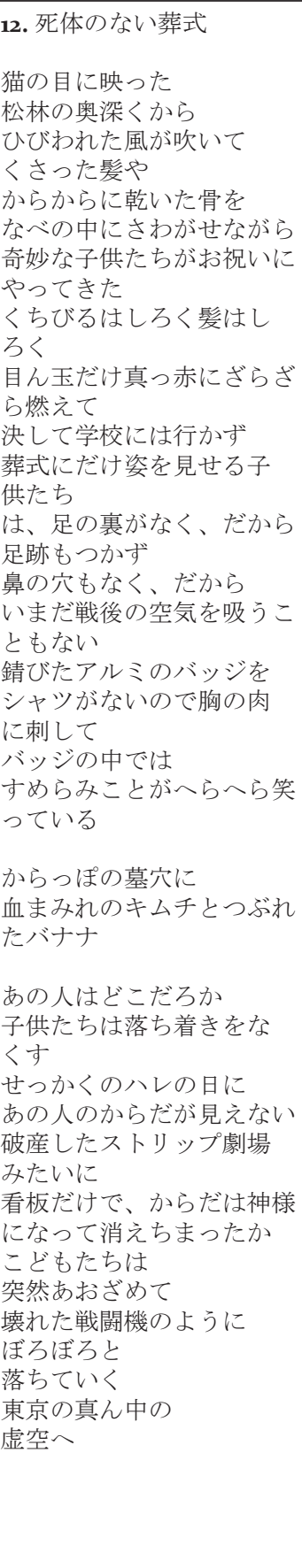 & $\begin{array}{l}\text { 12. Totenfeier ohne Leiche } \\
\text { Im Spiegel der Katzenaugen } \\
\text { weht } \\
\text { ein rissiger Wind } \\
\text { tief aus dem Kiefernhain } \\
\text { in ihren Töpfen rütteln sie } \\
\text { verrottetes Haar und trockene } \\
\text { Knochen } \\
\text { aus dem Schlaf: } \\
\text { Sonderbar sind die Kinder } \\
\text { die zum Festakt kamen } \\
\text { Weiß die Lippen weiß die } \\
\text { Haare } \\
\text { nur die Augäpfel brennen } \\
\text { tiefrot und rau } \\
\text { Die nie zur Schule gehn } \\
\text { nur zu Begräbnissen erschei- } \\
\text { nen die Kinder } \\
\text { Fußsohlen haben sie keine } \\
\text { keine Spuren hinterlassen sie } \\
\text { Auch Nasenlöcher haben sie } \\
\text { keine } \\
\text { atmen noch nicht die } \\
\text { Nachkriegsluft } \\
\text { Hemden haben sie keine } \\
\text { die rostigen Alusticker stecken } \\
\text { im Fleisch ihrer Brust } \\
\text { Vor ihnen lächelt servil und } \\
\text { verschlagen } \\
\text { Seine Heiligkeit der Tenno } \\
\text { Im leeren Grab } \\
\text { liegt blutiges Kim Chee- } \\
\text { Gemüse } \\
\text { aus Korea neben } \\
\text { zerquetschten Bananen } \\
\text { Wo ist er nur was meint ihr? } \\
\text { Die Kinder sind bestürzt } \\
\text { sogar an diesem heiligen Tag } \\
\text { ist sein Körper unsichtbar } \\
\text { Blieb nur ein Plakat } \\
\text { wie vor einem bankrotten } \\
\text { Striplokal } \\
\text { wurde sein Körper zum Gott } \\
\text { und verschwand? } \\
\text { die Gesichter der Kinder } \\
\text { werden plötzlich bleich } \\
\text { und wie Trümmer zerborste- } \\
\text { ner Kampflugzeuge } \\
\text { fallen sie } \\
\text { in die leere Mitte Tokyos }\end{array}$ & $\begin{array}{l}\text { 12. Funeral sem cadáver } \\
\text { refletido nos olhos do gato sopra } \\
\text { um vento rachado } \\
\text { do fundo do pinhal } \\
\text { chacoalham em suas panelas } \\
\text { cabelo podre e ossos secos } \\
\text { crianças estranhas } \\
\text { vieram para a cerimônia } \\
\text { brancos lábios brancos cabelos } \\
\text { apenas os globos oculares quei- } \\
\text { mam vermelhos e ásperos } \\
\text { nunca vão à escola } \\
\text { apenas nos funerais essas crianças } \\
\text { aparecem } \\
\text { elas não têm solas nos pés } \\
\text { não deixam pegadas } \\
\text { também não têm narinas } \\
\text { não respiram mais o } \\
\text { ar do pós-guerra } \\
\text { não têm camisas } \\
\text { as medalhas de alumínio corroídas } \\
\text { enterradas } \\
\text { na carne de seus peitos despidos } \\
\text { e de dentro das medalhas soa o } \\
\text { riso imbecil } \\
\text { de Sua Majestade, o Imperador } \\
\text { do Japão } \\
\text { no túmulo vazio } \\
\text { sangrento kimchi de acelga da } \\
\text { Coreia } \\
\text { e bananas esmagadas } \\
\text { onde está ele? } \\
\text { as crianças estão assombradas } \\
\text { mesmo neste dia sagrado } \\
\text { seu corpo é invisível } \\
\text { como a frente de um strip-club } \\
\text { falido } \\
\text { de que só restou o letreiro da } \\
\text { fachada } \\
\text { os rostos das crianças } \\
\text { de repente tornam-se pálidos } \\
\text { e como os estilhaços dos caças } \\
\text { destruídos } \\
\text { elas caem } \\
\text { no centro vazio de Tóquio }\end{array}$ \\
\hline
\end{tabular}




\begin{tabular}{|c|c|c|}
\hline 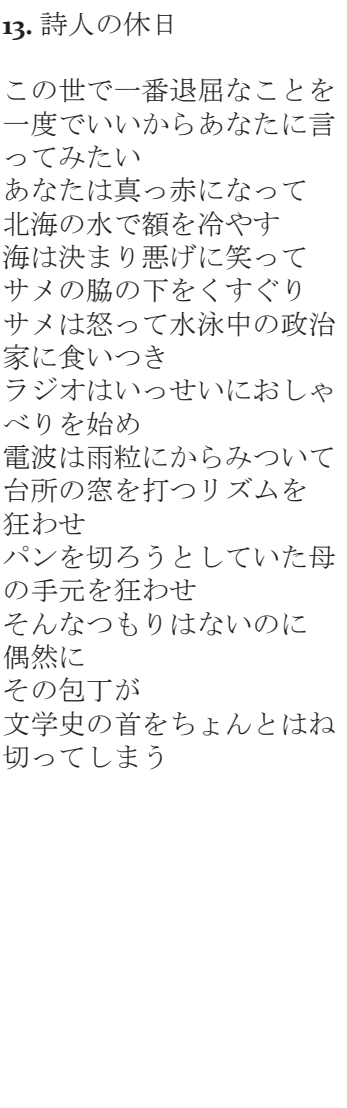 & $\begin{array}{l}\text { 13. Ein arbeitsfreier Tag der } \\
\text { Dichterin } \\
\text { Einmal möchte ich dir } \\
\text { die langweiligste Sache der } \\
\text { Welt sagen } \\
\text { Du wirst glutrot } \\
\text { und kühlst dir mit dem Was- } \\
\text { ser } \\
\text { der Nordsee die Stirn } \\
\text { Das Meer lacht verlegen } \\
\text { und kitzelt einen Hai unter } \\
\text { den Armen } \\
\text { Der Hai wird böse und beißt } \\
\text { einen Politiker } \\
\text { der gerade schwimmt Die } \\
\text { Radios } \\
\text { fangen gleichzeitig } \\
\text { ein riesiges Geschwätz an Die } \\
\text { elektrischen } \\
\text { Wellen } \\
\text { umschlingen die Wassertrop- } \\
\text { fen } \\
\text { dass das Klopfen am Küchen- } \\
\text { fenster } \\
\text { aus dem Takt gerät } \\
\text { und auch die Hand der Mutter } \\
\text { die das Brot schneiden wollte } \\
\text { Es war nicht geplant aber } \\
\text { zufällig } \\
\text { schneidet ihr Messer } \\
\text { den Kopf der Literaturge- } \\
\text { schichte ab }\end{array}$ & $\begin{array}{l}\text { 13. Um dia de folga da poeta } \\
\text { um dia hei de te contar } \\
\text { a coisa mais chata do mundo } \\
\text { você vai ficar vermelho como brasa } \\
\text { e vai refrescar a testa na água } \\
\text { do Mar do Norte } \\
\text { o mar vai rir maldoso } \\
\text { e vai fazer cócegas debaixo do } \\
\text { braço de um tubarão } \\
\text { o tubarão vai se zangar e morder } \\
\text { um político } \\
\text { que estava nadando } \\
\text { na mesma hora os rádios vão } \\
\text { começar a falar } \\
\text { as ondas eletromagnéticas vão se } \\
\text { misturar } \\
\text { aos pingos de chuva } \\
\text { que ao bater na janela da cozinha } \\
\text { sairão do compasso } \\
\text { desestabilizando a mão da minha } \\
\text { mãe } \\
\text { prestes a cortar o pão } \\
\text { não foi planejado } \\
\text { por acaso } \\
\text { sua faca corta de um golpe } \\
\text { a cabeça da História da Literatura }\end{array}$ \\
\hline
\end{tabular}




\begin{tabular}{|c|c|c|}
\hline 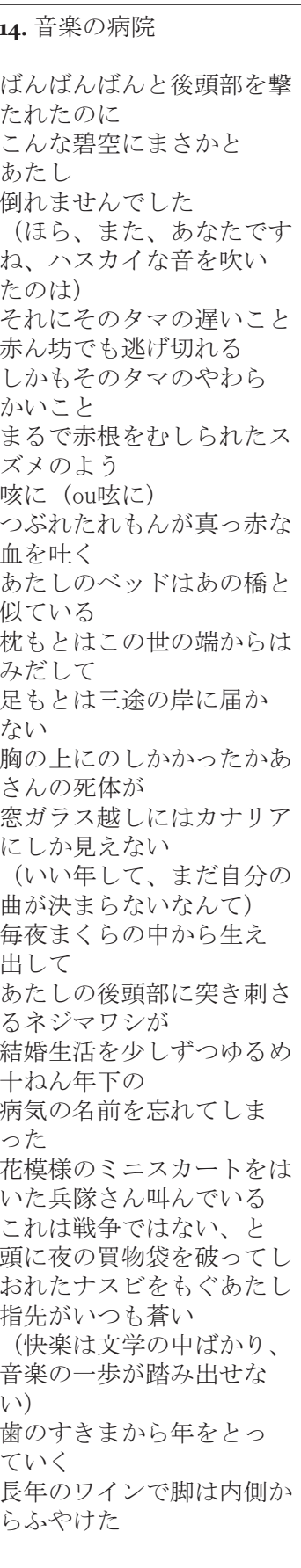 & $\begin{array}{l}\text { 14. Sanatorium Musicale } \\
\text { Trotz der drei Schüsse in } \\
\text { meinen Hinterkopf } \\
\text { bin ich } \\
\text { - bei diesem blauen Himmel! - } \\
\text { nicht gestorben } \\
\text { (Kam der schräge Ton schon } \\
\text { wieder von dir?) } \\
\text { Und dann die Langsamkeit } \\
\text { dieser Kugeln } \\
\text { Denen hätte ja ein Säugling } \\
\text { ausweichen können } \\
\text { Und dann die Weichheit dieser } \\
\text { Kugeln } \\
\text { Ganz wie gerupfte Spatzen } \\
\text { Die zerquetschte Zitrone } \\
\text { hustet blutrotes Blut } \\
\text { Mein Bett ist jener Brücke } \\
\text { ähnlich } \\
\text { das Kopfende steht auf dem } \\
\text { Rand der Welt } \\
\text { das Fußende reicht nicht bis } \\
\text { ans Ufer des Styx } \\
\text { Der Leichnam der Mutter } \\
\text { lehnt sich gegen meine Brust } \\
\text { durchs Glasfenster sieht er } \\
\text { nur wie ein Kanarienvogel aus } \\
\text { (Wie kannst du in deinem } \\
\text { Alter noch behaupten } \\
\text { dein Stück stehe nicht fest!) } \\
\text { Dieser Schraubenzieher der } \\
\text { jede Nacht aus dem } \\
\text { Kopfkissen wächst } \\
\text { und sich in meinen Hinterkopf } \\
\text { sticht } \\
\text { lockert das Eheleben ein wenig } \\
\text { - nach und nach } \\
\text { Wie lautet der Name } \\
\text { der zehn Jahre jüngeren } \\
\text { Krankheit nur? } \\
\text { Das ist kein Krieg! ruft der } \\
\text { Soldat } \\
\text { im blumenbedruckten Mini- } \\
\text { rock } \\
\text { Meine Fingerspitzen sind } \\
\text { immer blau } \\
\text { ich pflücke welke Auberginen } \\
\text { mit } \\
\text { Nachteinkauftaschen über den } \\
\text { Köpfen }\end{array}$ & $\begin{array}{l}\text { 14. Hospital Musical } \\
\text { bam! bam! bam! } \\
\text { mesmo com três tiros na nuca } \\
\text { - pelos céus! não estou morta } \\
\text { (olha só, vocês de novo com esse } \\
\text { som enviesado) } \\
\text { e como são lentas essas balas! } \\
\text { até mesmo um bebê poderia ter } \\
\text { desviado delas! } \\
\text { e, além disso, essas balas são } \\
\text { moles! } \\
\text { parecem mais pardais depenados } \\
\text { o limão espremido tosse sangue } \\
\text { vermelho } \\
\text { minha cama se parece com aquela } \\
\text { ponte } \\
\text { a cabeceira fica na borda do mun- } \\
\text { do } \\
\text { os pés não chegam às margens do } \\
\text { rio Sanzu } \\
\text { o cadáver da minha mãe apoia-se } \\
\text { em meu peito } \\
\text { do vidro da janela ele se parece } \\
\text { apenas com um canário } \\
\text { (você já está na idade } \\
\text { de decidir seu canto) } \\
\text { esta chave de fenda que cresce } \\
\text { todas as noites } \\
\text { de dentro do travesseiro } \\
\text { e entra em minha nuca } \\
\text { desaparafusa um pouco a vida } \\
\text { conjugal - pouco a pouco } \\
\text { não me lembro mais qual é o } \\
\text { nome } \\
\text { da doença de dez anos atrás } \\
\text { isto não é uma guerra! grita o } \\
\text { soldado } \\
\text { em minissaia de estampa floral } \\
\text { pego as sacolas de compras notur- } \\
\text { nas e rasgo na minha cabeça } \\
\text { junto berinjelas murchas do chão } \\
\text { por isso meus dedos estão sempre } \\
\text { tingidos de azul-escuro } \\
\text { (só existe prazer na literatura, } \\
\text { não consigo dançar conforme a } \\
\text { música) } \\
\text { eu envelheço pelas frestas entre } \\
\text { meus dentes } \\
\text { de tanto tomar vinho por tanto } \\
\text { tempo } \\
\text { a parte interna das coxas fica cheia } \\
\text { de pelancas }\end{array}$ \\
\hline
\end{tabular}




\begin{tabular}{|c|c|c|}
\hline 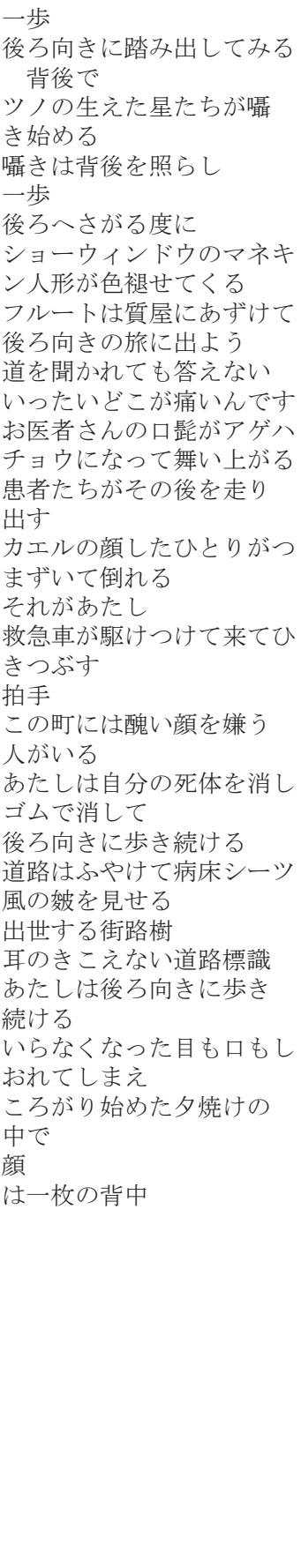 & $\begin{array}{l}\text { (Wollust gibts nur in der } \\
\text { Literatur die Musik } \\
\text { kommt keinen Schritt voran!) } \\
\text { Ich zähle die Jahre aus meinen } \\
\text { Zahnlücken } \\
\text { In langen Jahren sind vom } \\
\text { Wein die Innenseiten } \\
\text { der Beine aufgeweicht } \\
\text { EIN SCHRITT } \\
\text { Ich versuche rückwärts zu } \\
\text { gehen Im Hintergrund } \\
\text { beginnen die gehörnten Sterne } \\
\text { zu flüstern } \\
\text { EIN SCHRITT } \\
\text { Jedes Mal beim Rückwärts- } \\
\text { gehen } \\
\text { werden die Schaufensterpup- } \\
\text { pen fahl } \\
\text { Die Flöte kommt ins Pfand- } \\
\text { haus! } \\
\text { Dann geh ich rückwärts auf } \\
\text { Reisen! } \\
\text { Und wenn jemand nach dem } \\
\text { Weg fragt antworte } \\
\text { ich nicht } \\
\text { Na wo tuts denn weh? } \\
\text { Der Schnurrbart des Doktors } \\
\text { tanzt hoch empor } \\
\text { wie ein Schwalbenschwanz } \\
\text { Die Patienten laufen ihm nach } \\
\text { eine mit einem Froschgesicht } \\
\text { stolpert } \\
\text { und fällt um } \\
\text { Das bin ich } \\
\text { Ein Krankenwagen kommt } \\
\text { vorbei } \\
\text { und überfährt mich } \\
\text { Applaus } \\
\text { In dieser Stadt gibts Leute } \\
\text { die hassen hässliche Gesichter } \\
\text { Ich radiere meinen Leichnam } \\
\text { mit dem Radiergummi aus } \\
\text { und gehe rückwärts weiter } \\
\text { Die Straße weicht auf wirft } \\
\text { Falten } \\
\text { wie Laken auf Krankenhaus- } \\
\text { betten } \\
\text { Straßenbäume die Karriere } \\
\text { machen } \\
\text { Wegweiser ohne Ohren } \\
\text { Ich gehe rückwärts weiter } \\
\text { Welkt! Unnütze Augen unnüt- } \\
\text { zer Mund! }\end{array}$ & $\begin{array}{l}\text { um passo } \\
\text { decido andar de costas } \\
\text { ao fundo } \\
\text { estrelas chifrudas começam a } \\
\text { sussurrar } \\
\text { um passo } \\
\text { toda vez que ando de costas } \\
\text { os manequins das vitrines empa- } \\
\text { lidecem } \\
\text { a flauta está empenhada na casa } \\
\text { de penhores } \\
\text { então eu vou sair de viagem an- } \\
\text { dando de costas } \\
\text { e se alguém perguntar sobre o } \\
\text { caminho eu } \\
\text { não vou responder } \\
\text { e afinal onde é que dói? } \\
\text { o bigode do médico sai dançando } \\
\text { no ar } \\
\text { como uma borboleta-cauda-de- } \\
\text {-andorinha } \\
\text { os pacientes correm atrás dele } \\
\text { uma com cara de sapo tropeça } \\
\text { e cai } \\
\text { sou eu } \\
\text { uma ambulância vem } \\
\text { e passa por cima de mim } \\
\text { aplauso } \\
\text { nesta cidade existem pessoas } \\
\text { que odeiam caras feias } \\
\text { eu apago meu cadáver } \\
\text { com a borracha } \\
\text { e continuo caminhando de costas } \\
\text { a rua fica velha e enrugada } \\
\text { como lençóis em camas de hos- } \\
\text { pital } \\
\text { as árvores nas ruas são promo- } \\
\text { vidas } \\
\text { placas de trânsito surdas } \\
\text { eu continuo caminhando de costas } \\
\text { murchem! olhos inúteis boca } \\
\text { inútil } \\
\text { no rosado crepúsculo que começa } \\
\text { a se desenrolar } \\
\text { é o rosto } \\
\text { uma parte das costas }\end{array}$ \\
\hline
\end{tabular}


Exofonia do hóspede: poemas de Tawada Yôko - 826

\begin{tabular}{|l|l|l|}
\hline & Im Abendrot das sich aufzu- & \\
& rollen beginnt & \\
ist das & Gesicht & \\
& ein Streifen Rücken & \\
\hline
\end{tabular}

